\title{
Review \\ Immune Profiling of COVID-19 in Correlation with SARS and MERS
}

\author{
Bariaa A. Khalil ${ }^{1}$, Sarra B. Shakartalla 1,2, Swati Goel ${ }^{1}$, Bushra Madkhana ${ }^{1}$, Rabih Halwani ${ }^{1,3}$, \\ Azzam A. Maghazachi 1,3 ${ }^{(D)}$, Habiba AlSafar 4,5,6 (D) Basem Al-Omari 4,7,*(D) and Mohammad T. Al Bataineh 4,5,*
}

Citation: Khalil, B.A.; Shakartalla, S.B.; Goel, S.; Madkhana, B.; Halwani, R.; Maghazachi, A.A.; AlSafar, H.; Al-Omari, B.; Al Bataineh, M.T. Immune Profiling of COVID-19 in Correlation with SARS and MERS. Viruses 2022, 14, 164. https:/ / doi.org/10.3390/v14010164

Academic Editor: Andrew Davidson

Received: 27 December 2021

Accepted: 11 January 2022

Published: 17 January 2022

Publisher's Note: MDPI stays neutral with regard to jurisdictional claims in published maps and institutional affiliations.

Copyright: (C) 2022 by the authors. Licensee MDPI, Basel, Switzerland. This article is an open access article distributed under the terms and conditions of the Creative Commons Attribution (CC BY) license (https:// creativecommons.org/licenses/by/ $4.0 /)$
1 Sharjah Institute for Medical Research, College of Medicine, University of Sharjah, Sharjah P.O. Box 27272, United Arab Emirates; U19106038@sharjah.ac.ae (B.A.K.); u19106034@sharjah.ac.ae (S.B.S.); u19106040@sharjah.ac.ae (S.G.); u19106031@sharjah.ac.ae (B.M.); rhalwani@sharjah.ac.ae (R.H.); amagazachi@sharjah.ac.ae (A.A.M.)

2 Faculty of Pharmacy, University of Gezira, Wad Medani 2667, Sudan

3 College of Medicine, University of Sharjah, Sharjah P.O. Box 27272, United Arab Emirates

4 College of Medicine and Health Sciences, Khalifa University,

Abu Dhabi P.O. Box 127788, United Arab Emirates; Habiba.alsafar@ku.ac.ae or halsafar@moi.gov.ae

5 Center for Biotechnology, Khalifa University of Science and Technology,

Abu Dhabi P.O. Box 127788, United Arab Emirates

6 Emirates Bio-Research Center, Ministry of Interior, Abu Dhabi P.O. Box 389, United Arab Emirates

7 KU Research and Data Intelligence Support Center (RDISC) AW 8474000331,

Khalifa University of Science and Technology, Abu Dhabi P.O. Box 127788, United Arab Emirates

* Correspondence: basem.alomari@ku.ac.ae (B.A.-O.); mohammad.bataineh@ku.ac.ae (M.T.A.B.)

\begin{abstract}
Acute respiratory distress syndrome (ARDS) is a major complication of the respiratory illness coronavirus disease 2019 , with a death rate reaching up to $40 \%$. The main underlying cause of ARDS is a cytokine storm that results in a dysregulated immune response. This review discusses the role of cytokines and chemokines in SARS-CoV-2 and its predecessors SARS-CoV and MERS-CoV, with particular emphasis on the elevated levels of inflammatory mediators that are shown to be correlated with disease severity. For this purpose, we reviewed and analyzed clinical studies, research articles, and reviews published on PubMed, EMBASE, and Web of Science. This review illustrates the role of the innate and adaptive immune responses in SARS, MERS, and COVID-19 and identifies the general cytokine and chemokine profile in each of the three infections, focusing on the most prominent inflammatory mediators primarily responsible for the COVID-19 pathogenesis. The current treatment protocols or medications in clinical trials were reviewed while focusing on those targeting cytokines and chemokines. Altogether, the identified cytokines and chemokines profiles in SARS-CoV, MERS$\mathrm{CoV}$, and SARS-CoV-2 provide important information to better understand SARS-CoV-2 pathogenesis and highlight the importance of using prominent inflammatory mediators as markers for disease diagnosis and management. Our findings recommend that the use of immunosuppression cocktails provided to patients should be closely monitored and continuously assessed to maintain the desirable effects of cytokines and chemokines needed to fight the SARS, MERS, and COVID-19. The current gap in evidence is the lack of large clinical trials to determine the optimal and effective dosage and timing for a therapeutic regimen.
\end{abstract}

Keywords: chemokines; cytokines; COVID-19; MERS-CoV; SARS-CoV-2; SARS-CoV

\section{Introduction}

Coronaviruses (CoVs) are a group of enveloped, positive-sense, single-stranded RNA viruses belonging to Coronavirinae, a subfamily of Coronaviridae [1]. CoVs have the largest identified viral RNA genome with the ability to exert a variety of diseases with different severity in animals and humans [1,2]. CoVs are classified into $\alpha, \beta, \gamma$, and $\delta$ coronaviruses, with $\beta$-CoVs further subdivided into A, B, C, and D lineages [2]. Mainly $\alpha$ and $\beta$ infect humans with six genera identified; two of them belong to $\alpha-\mathrm{CoVs}$ (HCoV-229E and NL63) 
and the other four are part of the $\beta-\mathrm{CoVs}$ (HCoV-OC43, HCoV-HKU1, MERS-CoV, and SARS-CoV) $[1,3,4]$.

SARS-CoV and MERS-CoV cause severe acute respiratory syndrome (SARS) and the Middle East respiratory syndrome (MERS) respectively via zoonotic transmission [4-7]. The two viruses are mainly transmitted by respiratory droplets and possibly through feces among patients who present with varying symptoms ranging from a mild flu-like illness to atypical pneumonia, which can progress to acute respiratory distress syndrome (ARDS), multi-organ failure, and death $[4,7,8]$. The SARS outbreak which emerged in China in 2002 reported 8098 infected cases and a cumulative fatality rate of $9.6 \%$, whereas the MERS epidemic in 2012 reported 2494 confirmed cases and a fatality rate of $37.1 \%$, with the majority of cases being in Saudi Arabia $[9,10]$.

In December 2019, a new $\beta-\mathrm{CoV}$, the Severe Acute Respiratory Syndrome Corona Virus 2 (SARS-CoV-2), emerged for the first time in Wuhan, China, and then was announced as a pandemic in March 2020 [11]. More than two years into this pandemic, healthcare systems across the world continue to be overwhelmed with soaring daily cases [12]. Similar to SARS and MERS, the first case of SARS-CoV-2 occurred via zoonotic transmission linked to a seafood market and was capable of human-to-human transmission mainly via respiratory droplets $[13,14]$. SARS-CoV-2 causes the syndrome coronavirus disease 2019 (COVID19), as named by the WHO [15]. Similar to SARS-CoV and MERS-CoV, SARS-CoV-2 is considered a highly pathogenic human corona virus that shares $79.5 \%$ of the SARS-CoV genetic sequence and 50\% with that of MERS-CoV [16]. However, it is more aggressively transmitted, as over 267 million cases were confirmed as having caused over 5.2 million deaths in over 216 countries by the 10th of December 2021 [17]. The fatality rate in males is 2.4 times higher than in females [18], and there are higher co-morbidities in people over 60 years of age $[13,19]$.

The median incubation period post-SARS-CoV-2 infection is around 4-5 days, the symptoms appear within 11.5 days [20-23], the viral load reaches its peak in 5-6 days following the onset of symptoms as compared to 10 days for SARS-CoV [24-27], and ARDS occurs 8-9 days after symptoms' onset in severely diseased cases [28,29]. Generally, a majority of COVID-19 patients are asymptomatic or mildly symptomatic, with or without flu-like symptoms (81.4\%) [30]. The virus mainly infects the upper respiratory tract, but in $13.9 \%$ of patients, the infection can extend to the lower respiratory tract, causing severe pneumonia and leading, in some cases, to fatal acute lung injury (ALI) and ARDS, where patients require assisted ventilation and intensive-care therapy [29,30]. ALI and ARDS can progress to multi-organ failure or disseminated intravascular coagulation (DIC) with rare clinical recovery, making SARS-CoV-2 a major public health threat [20,31,32].

The main underlying cause of ARDS in SARS, MERS, and COVID-19 is the cytokine storm caused by proinflammatory mediators that exacerbate the host immune response [29,33-35]. Generally, cytokines and chemokines play an important role in the immunopathology of diseases caused by viral pathogens. Cytokines are molecular messengers, including interferon (IFN), interleukin, and growth factors, used by immune cells to communicate in a paracrine or autocrine fashion [36]. On the other hand, chemokines are small proteins that bind G-protein-coupled receptors (GPCR) to stimulate cell migration $[37,38]$. Chemokines share four cysteines with two characteristic disulfide bonds important for the conserved chemokine fold, and the spacing of the first two cysteines (adjacent (CCL), separated by an amino acid (CXCL) or separated by three amino acids $(\mathrm{CX} 3 \mathrm{CL}))$ is the basis for their systematic nomenclature [39].

The aim of this review is to examine the role, differences, and similarities in the profile of cytokines and chemokines during the pathogenesis of SARS, MERS, and COVID-19. It further highlights the most important findings to date about COVID-19 pathogenesis to better understand the virus behavior and identify therapeutic targets. This review discusses, in detail, the main treatment options targeting the chemokines and cytokines implicated in COVID-19 and their mechanism of action in ameliorating the severity of the disease; it then discusses the limitations and challenges in the current literature. 


\section{Search Strategy}

In this narrative review, a comprehensive literature search was conducted. Following Gasparyan and colleagues' recommendations [40], PubMed (MEDLINE), EMBASE, and Web of Science were electronically searched, without language or date restrictions. The keywords related to "Chemokines", "Cytokines" and "COVID-19", "MERS-CoV", "SARSCoV-2", and "SARS-CoV" were used with Boolean combinations. Additionally, several authors of this review are experts in the field, and opinions expressed in this review are also based on personal experience of writing, editing, and commenting on review articles.

\section{The Innate and Adaptive Immune Responses Associated with SARS-CoV-2 and the Correlation with SARS-CoV-2 and MERS-CoV Infections}

The entry of the SARS, MERS, and COVID-19 $\beta$-CoVs is facilitated by the S protein, which enables their replication inside host cells following the release of the viral RNA [41]. The $\mathrm{S} 1$ subunit of the homo-trimeric $S$ protein of SARS-CoV binds to angiotensinconverting enzyme 2 (ACE2) receptors on the alveolar cells, and the S2 subunit assists in the fusion of the viral membrane with the host cell [42,43]. Similarly, SARS-CoV-2 uses the $S$ protein to bind ACE2, yet attaches to the host cell with a higher affinity compared to SARS-CoV [44-47]. ACE2 is expressed on a variety of cells in the lungs and the gut, including epithelial cells of the airways and alveoli, vascular endothelial cells, and macrophages [48-51]. The transmembrane serine protease 2 (TMPRSS2) is also needed for SARS-CoV-2 entry [52]. On the other hand, the $\mathrm{S} 1$ subunit of the $\mathrm{S}$ protein of MERS-CoV binds to dipeptidyl peptidase 4 (DPP4/CD26), a type-II transmembrane glycoprotein that is expressed on multiple cells, including macrophages, fibroblasts, epithelial cells, and endothelial cells $[4,53,54]$. Moreover, MERS-CoV and SARS-CoV-2 exhibit the furin-like cleavage site, which is absent in SARS-CoV. This explains the difference in cellular tropisim and pathogenesis, since the furin-like cleavage site enhances viral fusion with host cell membrane [55].

Upon entry into the host's lung cells, the three $\beta$-CoVs cause cell destruction and trigger a local immune response. Despite the activation of lung macrophages by the $S$ protein of SARS-CoV, phagocytosis is dampened with the increase in cytokine production [56,57]. Similarly, the phagocytic function of macrophages and their ability to produce tumor necrosis factor-alpha (TNF- $\alpha$ ) and interleukin 6 (IL-6) were suppressed upon MERS-CoV binding to DPP4, indicating that MERS-CoV S protein could induce immune suppression by initiating signaling through DPP4 [54]. In addition, IL-1R-associated kinase (IRAK-M) and peroxisome proliferator-activated receptor- $\gamma$ (PPAR $\gamma)$, which is known to inhibit the activation of macrophages by toll-like receptor (TLR), were found to be upregulated by the $S$ protein, suggesting another molecular mechanism by which the immune system and cytokine production can be suppressed by MERS-CoV [54]. In SARS-CoV-2, the spleen and lymph nodes of six patients who died from COVID-19 showed a cluster of differentiation (CD) $68^{+}$and CD169+ macrophages expressing ACE2-SARS-CoV-2 complex, reflecting their importance in the viral spread and inflammation [58]. Furthermore, in comparison to mildly infected patients, severe COVID-19 patients showed an increase in the populations of the highly inflammatory monocyte-derived FCN1+ macrophages in their Broncho Alveolar Lavage Fluid (BALF) and the $\mathrm{CD} 14^{+} \mathrm{CD} 16^{+}$inflammatory monocytes in their peripheral blood [59]. Dendritic cells (DCs) also play a crucial role in viral spread and replication. Upon entry of SARS-CoV, DCs undergo functional modification, using DC-specific intracellular adhesion molecule-grabbing non-integrin CD209 receptors [60,61]. Furthermore, productive replication of MERS-CoV was demonstrated in monocyte-derived DCs [62]. In comparison with SARS-CoV, higher surface expression of major histocompatibility complex (MHC) class II Human Leukocyte Antigen-DR isotype (HLA-DR) and the co-stimulatory molecule CD86 were reported upon MERS-CoV infection, suggesting that the virus has a greater ability to activate monocyte-derived-DCs [62].

The activation of the innate immune cells induces the release of cytokines and chemokines that bring the adaptive immune system into action to fight viral infection. In SARS-CoV, 
two epitopes identified in the S protein resulted in high IFN- $\gamma$ production and T-cell response, which further augmented the humoral immunity against SARS-CoV infection [63]. However, the frequency of $\mathrm{CD}^{+}$and $\mathrm{CD} 8^{+} \mathrm{T}$ cells is reduced and priming by $\mathrm{DC}$ is also impaired [64]. For an unknown reason, the number of natural killer (NK) cells responsible for eliminating virus-infected cells is decreased in SARS-CoV [65]. The role of the adaptive immune system in MERS-CoV infection and, specifically, the role of cytotoxic $\mathrm{CD}^{+} \mathrm{T}$ cells, which are mainly responsible for viral clearance, were demonstrated in a replication-deficient adenovirus (Ad5-hDPP4)-transduced mouse model deficient for $\mathrm{T}$ and $\mathrm{B}$ cells [66]. Further, a transcriptomic study on bronchial epithelial cells infected with MERS-CoV indicated that the virus downregulates antigen-presenting proteins and major histocompatibility complex (MHC) I/II, and this, in turn, inhibits T-cell responses and allows the virus to evade the immune system [67]. Moreover, MERS-CoV impairs the function of $\mathrm{CD}^{+} \mathrm{T}$ cells upon binding to DPP4 and downregulating it, particularly because DPP4 has a critical role in the signal transduction pathways involved in T-cell activation $[68,69]$. Not only does MERS-CoV impair the function of $\mathrm{CD}^{+} \mathrm{T}$ cells, but it also induces intrinsic and extrinsic apoptosis, resulting in lymphopenia [70]. Post-SARS-CoV-2 infection, $\mathrm{T}$ - and B-cell responses are detected in the blood of infected patients around one week after the onset of symptoms [71]. Cytokine-secreting immune cells, such as $\mathrm{CXCR}^{+} \mathrm{CD}^{+}{ }^{\mathrm{T}}$ cells, $\mathrm{CXCR} 3^{+} \mathrm{CD}^{+}{ }^{+} \mathrm{T}$ cells, and $\mathrm{CXCR} 3^{+} \mathrm{NK}$ cells, were shown to be elevated in severe COVID-19 patients [72]. However, lymphocytes required to clear the virus, including $\mathrm{CD}^{+}$and $\mathrm{CD} 8^{+} \mathrm{T}$ cells, NKs, and $\mathrm{B}$ cells, were decreased in a directly proportional manner to disease. Collectively, these strategies delay the response of the adaptive immune system, resulting in inefficient viral clearance and the dissemination of the infection to extra pulmonary sites.

\section{The Role of Cytokines and Chemokines in SARS}

Studies on mice and patients post-SARS-CoV infection showed that proinflammatory cytokines and chemokines produced by airway epithelial cells (AECs), DCs, and macrophages have an important role in lung immunopathology and disease severity. IL-6, IL-8, IL-1 $\beta$, and TNF- $\alpha$ released by epithelial cells, pneumocytes, and macrophages of the lung and bronchial tissue are among the initial cytokines rapidly increasing in the blood of patients during early infection with SARS-CoV [73-76]. IL-6 and IL-1 $\beta$ stimulate the production of C-reactive protein (CRP), which mediates systemic inflammatory responses, while TNF- $\alpha$ stimulates fibroblast proliferation and collagen fiber synthesis, which subsequently cause pulmonary fibrosis [27,77-79]. As a result of the modification in their functions as discussed above, DCs release chemokines, such as CCL3 (macrophage inflammatory protein (MIP-1 $\alpha$ )), CCL5 (RANTES), CXCL10 (IP-10), and CCL2 (Monocyte Chemoattractant Protein-1 (MCP-1)), which induce the migration of inflammatory leukocyte cells [61]. By autocrine manner, these chemokines also enhance DC migration to lymph nodes to prime and activate T cells [80]. CCL2, CCL3, CCL5, CXCL10, and CCL10 are among the chemokines that drastically increased within $24 \mathrm{~h}$ and remained elevated after $48 \mathrm{~h}$ of infection [81]. Collectively, the increase in the aforementioned inflammatory mediators is an indicator of the host antiviral response.

In comparison to uncomplicated cases, severely infected patients with ARDS exhibit higher levels of the cytokines, i.e., IFN- $\alpha$, IFN- $\gamma$, IL-1, IL-6, IL-12, and TGF $\beta$, and the chemokines, i.e., CCL2, CXCL10, CXCL9, and IL-8 [34,82-86]. High concentrations of CCL2 and TGF- $\beta 1$ released by SARS-CoV-infected ACE2-expressing cells induce the migration of monocytes and macrophages from the blood stream to the injured lung, where they proliferate $\left(\mathrm{Mac} 387^{+}\right)$and get activated $\left(\mathrm{CD} 25^{+}\right)$to produce additional proinflammatory mediators that can worsen the disease [87-89]. In addition to its role in recruiting and activating macrophages and monocytes, TGF- $\beta 1$ contributes to the lymphopenia and thrombocytopenia detected in SARS patients by enhancing Fas-mediated cell apoptosis, consequently leading to the death of alveolar epithelial cells, lymphocytes, and platelets [90-92]. Another possible underlying cause for lymphopenia is the impaired DC function, being the only 
antigen-presenting cell capable of priming $\mathrm{T}$ cells, and this is probably attributed to the action of proinflammatory cytokines IL-6 and IL-8 [93]. Further, the cytokines produced by Th2 cells, such as IL-4 and IL-10, were shown to decrease post-SARS infection, suggesting that the immune response is dominated by Th1 rather than Th2 cells $[83,94]$. Moreover, IL- 4 and with IFN- $\gamma$ were demonstrated to inhibit SARS-CoV replication partly by ACE2 downregulation [95]. However, elevated levels of IL-10 were also detected in some SARS patients, and this was attributed to the dual effect of IL-10 on T lymphocytes, whereby it inhibits the production of IL-2, IFN, and TNF from Th1 and activates cytotoxic CD8 ${ }^{+}$ $\mathrm{T}$ cells and NKs, hence increasing susceptibility to the disease [94]. The discrepancy in IL-10 fluctuation post-SARS infection is also seen in IL-2 expression, where some studies reported high-expression post-SARS onset, whereas others did not $[34,96,97]$.

Regarding IFNs, elevation in the levels of IFN- $\alpha 2$, IFN- $\beta 1$, and IFN2 was demonstrated within $24 \mathrm{~h}$ of infection suggesting the involvement in plasmacytoid DCs and monocytes in the early stage of the disease [81]. Furthermore, the binding of Toll-like receptor 3 (TLR3), TLR7, and retinoic acid-inducible gene I (RIG-1)-like receptors (RLRs) to SARS-CoV-pathogen-associated molecular patterns (PAMPS) and viral RNA initiates a downstream signaling cascade, resulting in the production of proinflammatory cytokines, mainly type 1 interferon (IFN), which limits the active replication of the virus [98,99]. However, post-SARS-CoV infection, IFN secretion is dysregulated, and excessive proinflammatory cytokines are released, leading to inefficient innate immune response [100]. Dysregulation in IFN production ( $\alpha$ and $\gamma$ ) and IFN-stimulated genes (ISGs) transcription is mediated through different mechanisms by SARS-CoV and have a major contribution to disease pathogenesis $[76,98]$. The binding of SARS-CoV RNA to TLR3, RIG-I, and MDA-5 receptors leads to the phosphorylation, activation, and nucleus translocation of the IFN regulatory factor 3 (IRF-3) and IRF7, resulting in IFN- $\alpha / \beta$ synthesis [101,102]. IFN- $\alpha / \beta$ binds to IFN receptors (IFNR) present on all nucleated cells and activates signal transducer and activator of transcription (STAT) proteins through phosphorylation by Janus kinase 1 (JAK1), thus promoting the transcription of IFN-stimulated genes (ISGs) that exhibit antiviral properties [103]. However, SARS-CoV forms perinuclear double-membrane vesicles (DMVs) in the host cell for its RNA synthesis [104]. This may help in avoiding recognition by PPRs and the production of IFN- $\alpha / \beta$ [105]. Moreover, the open reading frame (ORF) $3 b$ and ORF6 encoding the nucleocapsid $(\mathrm{N})$ protein of SARS-CoV inhibit IRF-3 translocation to the nucleus and downregulate the production of TGF- $\beta$ [106]. Furthermore, ORF6 inhibits STAT1 translocation to the nucleus and suppresses ISGs transcription [107]. Another mechanism by which SARS-CoV inhibits IFN secretion is via its membrane papain-like protease (PLpro-TM) that inhibits the STING/TBK1/IKK $\varepsilon$ pathway required for the phosphorylation and dimerization of IRF3 [108]. Studies on mice infected with SARS also showed that virus replication is associated with delayed IFN1 signaling, which is responsible for the accumulation of inflammatory monocytes and macrophages, elevation in the levels of cytokines and chemokines, impairment of adaptive immunity, and development of vascular leakage [109]. IFN also tends to upregulate inhibitory molecules (PDL-1) on T cells, resulting in impaired adaptive immune response upon viral infection [110]. Moreover, interferon- $\gamma$-induced protein CXCL10 secreted by monocytes, endothelial cells, and fibroblasts is prominent in SARS-CoV patients and one of the early chemokines increased in blood and lung tissue with its level increasing with the rise in infection and returning to normal during recovery $[73,111]$. Upon binding to its receptor CXCR3, CXCL10 recruits monocytes, macrophages, DCs, NK cells, and T lymphocytes toward interstitial lung tissue and induces inflammation in SARS patients [112].

\section{The Role of Cytokines and Chemokines in MERS}

Upon infecting the human airway epithelial cells, MERS-CoV induces delayed, yet significant and higher levels of the proinflammatory cytokines IL- $1 \beta$, IL-8, and IL-6 as compared to SARS-CoV [113]. IL-1 $\beta$ and IL- 8 are important mediators of ARDS, whereby IL-8 recruits and activates neutrophils, which in turn recruit more immune cells [6,113-116]. 
As for IL-6, a significant release by MERS-infected human-monocyte-derived macrophages and by the lung lesions of infected animals was detected $[117,118]$. IL-6 is associated with disease progression and severity, since higher levels were observed in the second and third week of illness in a severe MERS group of patients compared to the mild group [119]. Furthermore, very low levels of innate antiviral cytokines, such as TNF- $\alpha$, IFN- $\beta$, and CXCL10, were induced by MERS-CoV compared to SARS-CoV [113]. In line with these findings, MERS-CoV was unable to induce antiviral TNF- $\alpha$, IFN- $\beta$, and CXCL10 in the human alveolar basal epithelial cell line (A549 cell line) [120]. These findings indicate that MERS attenuate innate immunity and has a greater ability to evade the antiviral response compared to SARS-CoV. However, CXCL10 was also reported to be associated with disease severity, since persistent high levels were reported in the serum of a patient who died post-MERS infection [121]. This was further supported by a serum analysis study on nine severely infected MERS patients with higher levels of CXCL10 observed as the disease progress specifically in the second and third week after onset of symptoms [119]. Another in vitro study comparing the levels of cytokines and chemokines released by blood-monocyte-derived macrophages and DCs upon MERS-CoV or SARS-CoV infection demonstrated higher levels of IFN- $\gamma$, IL-12, IL-8, CCL2, CCL3, CCL5, and CXCL10 postMERS-CoV as compared to SARS-CoV, while comparable levels of TNF- $\alpha$ and IL- 6 were displayed [62,117]. Moreover, IFN- $\alpha$, CXCL10, IL-6, IL-8, and CCL2 were detected on day 11 in patients' serum, and their levels decreased upon clinical improvement [122]. Cytometric bead array analysis of the cytokine profile of seven laboratory-confirmed MERS patients further showed high levels of the cytokines IFN- $\alpha 2$, IFN- $\gamma$, IL-10, TNF- $\alpha$, IL-15, and IL-17, whereas no difference in the levels of IL-12, IL-2, IL-4, IL-5, IL-13, and TGF- $\alpha$ was observed [33]. IL-17 plays an important role in recruiting neutrophils and monocytes, which produce IL-1 $\beta$, IL-6, TNF- $\alpha$, TGF- $\beta$, IL-8, and CCL2 collectively implicated in airway remodeling $[33,123]$. Clinically, high levels of cytokines and chemokines in the serum of MERS-CoV-infected patients were found to be associated with increased neutrophil and monocyte counts in the peripheral blood and lungs of MERS patients $[113,119,124]$. It is worth noting that the discrepancy in the levels of some chemokines and cytokines, such as CXCL10, TNF- $\alpha$, and IL-6, between in vitro and in vivo studies could be attributed to the absence of the physiological setting or different measurement timing. This suggests that there is an interplay between the different inflammatory mediators, and studying a particular chemokine or cytokine at a time will probably provide an incomplete conclusion about its role in disease pathogenesis.

Regarding IFN, an in vitro study on monocyte-derived-DCs infected with MERS-CoV showed no expression of the anti-inflammatory IFN- $\beta$, marginal expression in IFN- $\alpha$, and higher expression in IFN- $\gamma$ as compared to SARS-CoV [62]. Another study assessing the levels of IFN- $\alpha$ in two MERS patients showed that a higher expression level of IFN- $\alpha$ in the broncho-alveolar lavage cells was correlated with survival of one patient, whereas its absence was associated with the death of the other [121]. The reduction in IFN- $\alpha$ expression was explained by the decrease in IRF-3 and IFR-7 observed in the deceased patient [121]. Furthermore, IL-12 and IFN- $\gamma$ were also detected with IFN- $\alpha$, suggesting a critical role of IFN- $\alpha$ in the development of an early antiviral Th1 adaptive immune response mediated by the release of IL-12 and IFN- $\gamma$ against MERS-CoV infection [121]. An elevation in the level of IL-10 was detected in the serum of a MERS-CoV patient $0-3$ days post-infection and was found to be correlated with persistence of viral infection, especially since higher levels were observed in the patient who did not tolerate the infection compared to the recovered patient [121]. Not only does IL-10 activate the JAK/STAT signaling pathway, resulting in the production of more proinflammatory cytokines, but it can also inhibit IFN- $\gamma$ production thereby reducing $\mathrm{CD}^{+}$T-cell proliferation and increasing MERS-CoV replication [121,125]. Taken together, it can be suggested that IFN- $\alpha$ is a major component of the antiviral host response against MERS-CoV, as its absence is associated with a worse outcome. 


\section{The Role of Cytokines and Chemokines in COVID-19}

Pyroptosis or inflammatory programmed necrosis is an important process that contributes to the inflammation associated with SARS-CoV-2 infection and to the activation of the adaptive immune system $[126,127]$. The destruction of virally infected cells produces PAMPs, viral RNA, and damage-associated molecular patterns (DAMPs) which bind to their respective pattern-recognition receptors (PRRs) on alveolar epithelial cells and macrophages and induce pyroptosis and the release of proinflammatory cytokines, mainly IL-1 $\beta$ and IL-18 [29]. Furthermore, other cytokines and chemokines, such as IL-6, IFN- $\gamma$, CCL2, and CXCL10, are released and polarize T helper cells to activate B cells and cytotoxic $\mathrm{CD}^{+} \mathrm{T}$ cells, thus bringing the adaptive immune system into action in the airways to control the viral infection [128]. Real-time polymerase chain reaction (RT-PCR) and next-generation sequencing on SARS-CoV-2-infected patients showed an initial elevation in the plasma levels of IL-1 $\beta$, IL-1RA, IL-7, IL-8, IL-10, IFN- $\gamma$, CCL2, CCL3, CCL4, CCL7, and granulocyte colony-stimulating factor (G-CSF), whereas the levels of IL-6, IL-2, IL-7, IL-17, IL-10, CCL3, IL-8, CXCL10, and TNF- $\alpha$ were shown to be continuously elevated in severely infected patients [29]. The elevation of these cytokines and chemokines indicates hyperactivation of Th1 cells [129]. Transcriptomic analysis on patients' BALF also showed elevated levels of TGF- $\beta$, CXCL1, IL-10, CCL2, CXCL2, CCL8, CCL3, CCL4, CXCL10, IL-33, IL-8, and CXCL6 [130]. Moreover, CXCL17, a macrophage chemoattractant, is among the chemokines that were firstly upregulated in all SARS-CoV-2 patients whose BALFs were analyzed for meta-transcriptome sequencing, and functional analysis suggests an important role of CXCL17 in COVID-19 pathogenesis [131]. IL-8, CXCL1, CXCL2, and their respective receptors were also upregulated in the same patients, being critical for the recruitment of neutrophils to the lungs [131-134]. This finding was consistent with the high neutrophilto-lymphocyte ratio particularly in patients with high viral load, cytokine levels, and ISG expression [131]. In addition to CXCL8, IL-10, TNF- $\alpha$, IL-15, and IL-27 were shown to be positively correlated people of an older age (above 60) who present a significant reduction in the total T-lymphocyte number and an increased expression of T-cell exhaustion markers as compared to younger infected individuals [135]. Defining age-associated immune profile in SARS-CoV-2-infected patients aids in identifying preventive and therapeutic strategies, especially that age is a key factor in COVID-19 morbidity and mortality. Collectively, all the cytokines and chemokines contribute to COVID-19 immunopathology, yet IL-6, IFN, IL-17, TGF- $\beta$, TNF- $\alpha$, and CXCL10 are believed to have major roles in the lung pathogenesis post-SARS-CoV-2 infection.

\section{1. $I L-6$}

COVID-19 activates $\mathrm{CD}^{+} \mathrm{T}$ cells to differentiate into pathogenic Th1 cells, which release GM-CSF and other proinflammatory cytokines that further activate monocytes to release IL-6 [136]. IL-6 can also be released from macrophages and DCs infected with SARSCoV-2 [137]. IL-6 binds to its receptors on immune and non-immune cells and activates the downstream JAK-STAT3 and JAK-SHP-2 mitogen-activated protein (MAP) kinase pathway, resulting in the release of vascular endothelial growth factor (VEGF), CCL2, IL-8, and additional IL-6 [138]. Furthermore, IL-6 also decreases the expression of E-cadherin on endothelial cells, leading, together with VEGF, to an increase in vascular permeability and leakage, eventually resulting in the hypotension and pulmonary dysfunction seen in SARS-CoV-2 infection [138]. A meta-analysis of nine studies from China that studied 1426 patients supported the role of IL-6 in COVID-19 virulence. It was demonstrated that IL6 was elevated in the serum of severely infected patients experiencing respiratory distress and admitted to the ICU, hence making IL-6 an important marker to evaluate disease severity and early stratify patients at risk to progress into complications [139]. Moreover, IL-6 is responsible for the elevation in CRP, serum amyloid A, fibrinogen, and hepcidin and the inhibition of albumin synthesis [139]. Conversely, another study that investigated the link between lymphocyte subsets, cytokine release, pulmonary inflammation index (PII), and disease evolution showed a zero value of IL-6 in mildly infected patients in half 
of the study population. They determined this finding to be caused by the inhibition of Th2 involved in humoral immunity in an early stage of infection, hence emphasizing the importance of IL-6 as a marker of disease severity [140]. In addition, no significant change in the transcription levels of IL-6 in PBMC of COVID-19 patients was detected, indicating that the source of IL-6 in the serum is mainly the lung epithelial cells [130]. Furthermore, the expression level of IL-6R was lower in the BALF of COVID-19 patients compared to controls with no difference on PBMCs, suggesting that the IL-6/IL6R axis in the epithelial cells of the lungs is the one involved in the immunopathology of the disease [130].

Another effect of IL-6 is the ability to inhibit HLA-DR expression on CD14 monocytes [141]. This was detected in COVID-19 patients with high serum levels of IL-6 and low HLA-DR on their CD14 monocytes, along with a low lymphocyte count [142]. In contrast, less severe patients with lower levels of IL-6 showed higher circulating HLA-DR cells [71]. Not only does IL-6 cause defective lymphoid function, but it also impairs the function of NK cells in clearing virally infected cells and reduces their cytotoxic effect specifically by inhibiting the perforin and granzyme B through blocking the STAT5 signal transduction required for regulating perforin transcription $[143,144]$. These results pinpoint the role of IL-6 not only in inducing the cytokine storm in COVID-19 patients but also in affecting the function of lymphoid cells, suggesting that IL-6 plays a key role in dysregulating adaptive immunity and consequently dampening the host's ability to fight the virus.

\subsection{IFN}

Type 1 and type III IFN responses are considered to be the major first antiviral defense mechanism elicited by the innate immune sensors [145]. Upon binding to the ubiquitously expressed type I IFN receptor (IFNAR), type I IFNs (IFN- $\alpha$, IFN- $\beta$, IFN- $\varepsilon$, IFN- - , and IFN- $\omega$ in humans) activate interferon-stimulated genes (ISGs), which interfere in viral replication [146]. On the other hand, type III IFNs (IFN- $\lambda$ ) bind to the type III IFN receptor (IFNLR) expressed on epithelial cells and certain myeloid cells [147]. Accordingly, suppressing or modulating the functions of IFNs and ISGs is considered one successful mechanism for viral pathogens to bypass the immune system. This applies as well to the highly pathogenic coronaviruses, which use various mechanisms to evade and suppress the IFN response, including IFN production, signaling, and ISG effector function, despite the powerful host antiviral strategy [145]. However, in addition to viral factors, host factors are important determinants of the IFN signaling outcome in being protective or pathogenic against a particular viral pathogen. For instance, the age of the host affects the cytokine profile and disease pathogenesis, due to differences in the imbalance between pro-inflammatory versus IFN response in different age groups. A study on aged macaques that were infected with SARS-CoV showed more lung pathology and higher expression of pro-inflammatory cytokines but lower expression of IFN-Is in older macaques compared to younger macaques [148].

Several studies highlighted the role of IFN in the immunopathology of COVID-19 patients. During SARS-CoV-2, interferon signaling was detected to be the highest upregulated pathway by the global functional analysis performed on meta-transcriptome sequencing data on the BALF of COVID-19 patients [131]. This observation was accompanied by a marked elevation in ISGs and interferon-induced transmembrane proteins (IFITMs), which were shown to inhibit the cellular entry of SARS-CoV and MERS-CoV $[131,149,150]$. It is worth mentioning that the IFN response triggered in SARS-CoV-2 is more robust and protective as compared to SARS-CoV; this might explain the lower proportion of severe cases and fatality rate of COVID-19 compared to SARS [32]. Nevertheless, the study did not detect significant upregulation of IFNs, despite the increase in ISGs, suggesting that SARS-CoV-2 might be delaying IFN production by inhibiting innate immune signaling, and this discrepancy needs further investigation [131]. Another study revealed upon conducting transcriptome profiling of various cell types that SARS-CoV-2 infection elicits very low IFN-I or IFN-III and limited ISG response while inducing chemokine and pro-inflammatory cytokine genes [151]. Interestingly, a small COVID-19 patient cohort revealed that levels 
of IFN- $\alpha$ and ISGs were associated with the viral load, as well as disease severity, thus indicating that severe infections lead to high IFN signatures but fail to bring down viral load [152].

Regarding the possible mechanism that SARS-CoV-2 uses to antagonize the antiviral effect of IFN, it was postulated that the non-structural proteins 4a (NS4a) and NS4b shared between MERS and SARS-CoV-2 that are known to suppress IFN- $\lambda$ production from lung epithelial cells are being used by SARS-CoV-2 to evade the immune system $[153,154]$. When compared to SARS-CoV, which shares greater than $90 \%$ amino acid identity with SARS-CoV-2, proteins antagonizing IFN, such as nsp3, ORF3b, ORF6, have relatively lowsequence homology [155]. In SARS-CoV-2, ORF3b contains a premature stop codon that results in a truncated protein, and ORF6b is missing two amino acids at the C-terminal critical for the protein function [107]. This may explain the enhanced susceptibility of SARSCoV-2 to IFNs as compared to SARS-CoV [155]. This runs parallel to in vitro observations that reported that SARS-CoV infection does not induce significant IFN-I production and with clinical studies which reported a lack of IFN response in SARS patients despite the robust production of cytokine and chemokine $[108,156]$.

In this regard, it is crucial to mention that the cytokine and chemokine profile differs in the different stages during COVID-19 infection, as reported by several studies [145]. In turn, the temporal kinetics of the cytokine/chemokine profile can reflect the inflammatory mediators contributing to disease severity and provide an idea about the treatment modality to be used at different stages. This applies as well to IFN-1 induction, where the timing of exogenous IFN administration relative to viral replication is a key determinant of the response outcome. Accordingly, IFN-1 supplementation is most beneficial when given early in the disease course, when IFN-I expression is delayed or reduced due to viral suppression of IFN response or the older age of the host [145].

\section{3. $I L-17$}

Severely infected COVID-19 patients exhibit significantly elevated numbers of CCR6 + Th17 cells [157]. The immune response of Th17 is influenced by the cytokines and chemokines released in response to SARS-CoV-2 infection, including IL- $1 \beta$ and TNF$\alpha$ [158]. In turn, Th17 produces IL-17, GM-CSF, IL-21, and IL-22, among which IL-17 was detected to be involved in the immune response against SARS-CoV-2 via releasing proinflammatory cytokines, such as G-CSF, which induces granulopoiesis and recruits neutrophils; and IL- $1 \beta, \mathrm{IL}-6$, and TNF $\alpha$, which collectively cause systemic inflammatory response [158]. Furthermore, Th17 induces the release of CXCL1, CXCL2, IL-8, CXCL10, and CCL20, which attract more immune cells to the injured lung, in addition to the release of metalloproteinases responsible for tissue damage and remodeling [158]. These effects of Th17 reflect its contribution to the cytokine storm and pulmonary edema, making it an important target for therapy in COVID-19 patients. However, in contrast to IL-6, IL-17 did not demonstrate a significant difference between severely and mildly infected patients [140].

\subsection{TGF- $\beta$}

TGF- $\beta$ is an anti-inflammatory cytokine released upon SARS-CoV-2 infection [130]. In response to SARS-CoV- 2 infection, TGF- $\beta$ is released from different sources, including the dysregulated coagulation and fibrinolytic pathways; the neutrophils massively infiltrating the lungs; and the macrophages migrating to the lungs to phagocytize apoptotic bronchial epithelial cells, pneumocytes, T-lymphocytes, and neutrophils [159]. The effect of this cytokine in SARS-CoV-2 infection is explained by its ability to recruit more neutrophils and remodel the airways by regulating processes used by the virus to develop pulmonary fibrosis. Pulmonary fibrosis seen in the lung biopsy of patients occurs through promoting myelofibroblast differentiation and fibroblast proliferation [157,159-161]. Eventually, this leads to failure in pulmonary function and death, hence making TGF- $\beta$ an important target for therapy. 


\section{5. $T N F-\alpha$}

TNF- $\alpha$ is a proinflammatory cytokine released by macrophages and monocytes during acute inflammation and was found to be elevated in COVID-19 patients in general; however, more pronounced levels were detected in severe cases [29]. TNF- $\alpha$ amplifies inflammation by enhancing oxidative stress and leukocyte adhesion to the epithelium, modulating blood coagulation, and inducing fever indirectly [162]. Based on the structural homology between SARS-CoV and SARS-CoV-2, it is hypothesized that the same strategy to release TNF- $\alpha$ is used by both viruses, characterized by the modulation of TNF- $\alpha$-converting enzyme (TACE)-dependent shedding of the ACE2 ectodomain, using viral spike protein [163].

\subsection{CXCL10}

Similar to SARS and MERS, CXCL10 is significantly elevated in COVID-19 patients. Analysis of 48 cytokines in the plasma of 50 COVID-19 patients showed that CXCL10 is an important biomarker for disease severity, and its increase was associated with an elevation in CCL7 (monocyte-chemotactic protein 3 (MCP3)) [164]. Taken together, CXCL10 and CCL7 can be excellent predictors for disease progression, especially since the CXCL10-CXCR3 signaling pathway was shown to play an important role in ARDS pathogenesis [165].

\section{How Does the Immune Profiling in COVID-19 Correlate with SARS and MERS?}

Based on the comparison between various inflammatory mediators involved in SARS, MERS, and COVID-19 immunopathology, it is concluded that common chemokines and cytokines profiles are shared among patients infected with the three viruses. Moreover, the same important chemokines and cytokines contributing to disease severity are involved in the three $\beta-\mathrm{CoVs}$, such as the delay in the production of antiviral IFN and the elevation of IL-6, IL-17, CXCL10, TNF- $\alpha$, and TGF- $\beta$. This implies that SARS-CoV, MERS-CoV, and SARS-CoV-2 use similar mechanisms for escaping the immune system, virus replication, dissemination, and disturbing the innate immune response, causing the cytokine storm. This can be attributed to the genetic and structural homology between the three $\beta$-CoVs. However, despite the similarities in the cytokine and chemokine profile, SARS, MERS, and COVID-19 have different rates of transmission and mortality, reflecting evolutionary differences in viral behavior that need to be further investigated. In addition, SARS-CoV-2 cytokine storm is not restricted to the elderly with co-morbidities but is also a threat to young healthy individuals with no risk factors. This can be attributed to the different mutations of SARS-CoV-2 and the different genetic makeup in individuals that define their tolerance for the infection [166].

Furthermore, based on the role of cytokines and chemokines in the immunopathology of COVID-19, the need to measure inflammatory mediators by developing a scoring system with cutoff values became a necessity, especially considering the practicality of blood tests in comparison to CT scans. IL-6, IFN, and CXCL10 stand to be important markers for disease severity. In addition, ratios of some cytokines and chemokines can be used, such as IL-6/IFN- $\gamma$ ratio, which was demonstrated in a meta-analysis to be elevated in severe COVID-19 patients compared to mild cases and linked to the interaction between IFN- $\gamma$ and IL-6/sIL-6R signaling $[167,168]$. However, practically not all cytokines can be easily assessed in peripheral blood, such as IFN- $\gamma$ and IL-1 $\beta$ [143]. However, evaluating the inflammatory mediators that can be measured in blood or serum especially those of prominent importance in disease severity will help in detecting patients at risk of progressing to a severe state and allow for early preventive measures that can eventually reduce the mortality rate.

\section{Treatments Targeting Chemokines and Cytokines in COVID-19}

The immune system plays a major role in infections caused by $\beta$-CoVs and the various players, including immune cells, chemokines, cytokines, and immune checkpoints, can be considered potential targets for therapy. However, based on our review, cytokines and 
chemokines are the main underlying reason for complications and mortality. Drugs in clinical trials or those currently used can target these inflammatory mediators directly or indirectly either by targeting the immune cells that produce them or simply by inhibiting the virus entry and replication, which hinder the inflammatory reaction. This section discusses the different drugs that are currently being tested or used to directly inhibit the proinflammatory effects of chemokines and cytokines based on the immune profile of COVID-19 patients, while focusing on the inflammatory mediators with prominent importance in disease severity (Table 1). This will shed light on the possible treatments that might help in preventing the transition from a mild disease state to a severe one, which, in most cases, leads to death. Several drugs currently used against COVID-19 patients or being tested in clinical trials that target the various chemokines and cytokines responsible for the cytokine storm in COVID-19, including IL-6 inhibitors, IFN, IL-1 $\beta$ inhibitors, JAK inhibitors, and IL-17 antibodies, are illustrated (Figure 1).

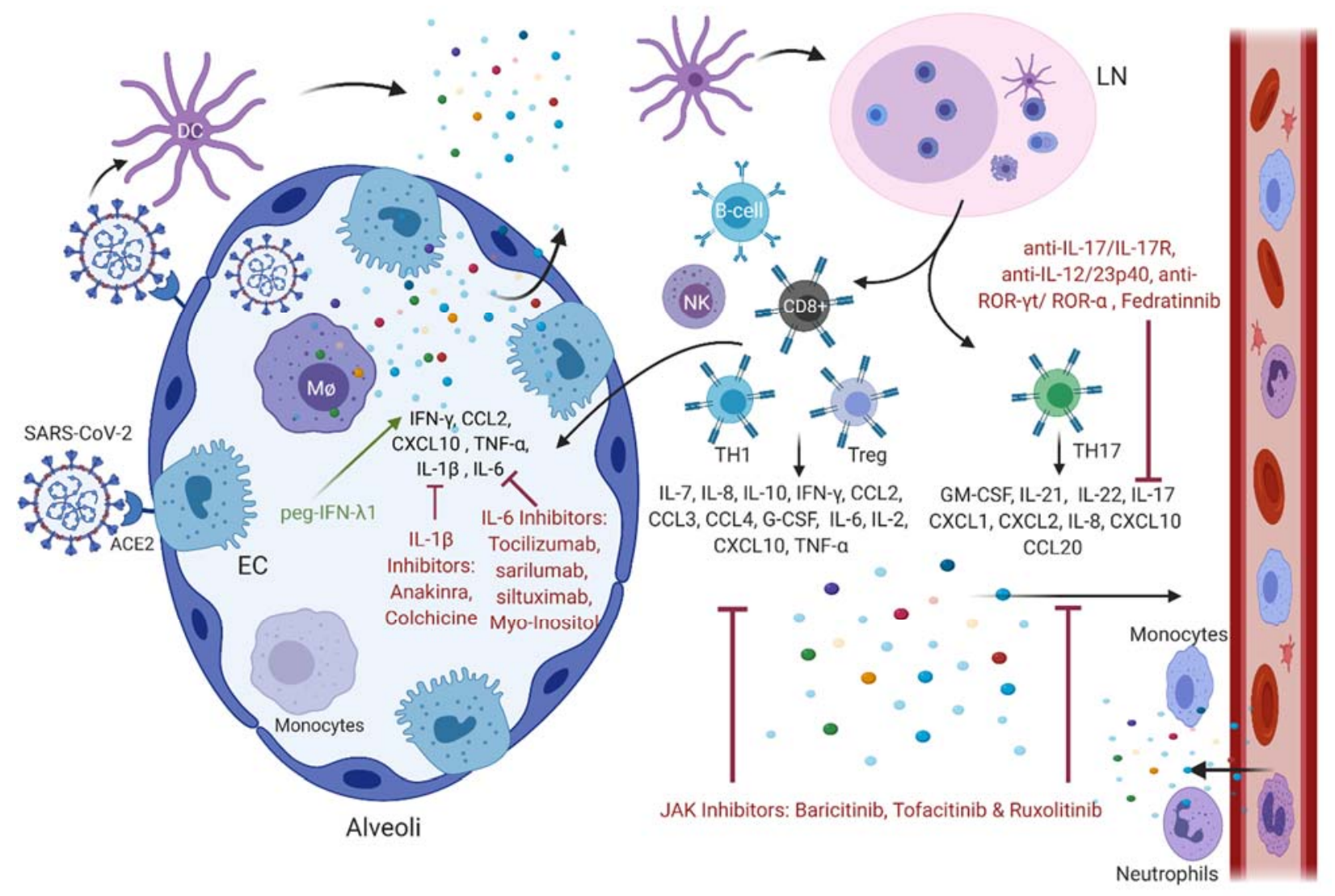

Figure 1. Innate and adaptive immune cells involved in SARS-CoV-2 infection, as well as the different chemokines and cytokines released and their inhibitors. SARS-CoV-2 binds ACE2 receptor on epithelial cells (ECs) and on macrophages $(M \Phi)$ of the alveoli. This triggers the release of cytokines and chemokines that attract more immune cells to the injured lung. Upon infection, activated DCs migrate to the lymph node (LN), where they activate T- and B-lymphocytes, which will further release pro-inflammatory mediators that exacerbate the infection. Several drugs currently used on patients or being tested in clinical trials target the various chemokines and cytokines responsible for the cytokine storm in COVID-19, including IL-6 inhibitors, INF, IL-1 $\beta$ inhibitors, JAK inhibitors, and IL-17 antibodies. 
Table 1. Summary of the common cytokine and chemokine profile of patients infected with SARS-CoV, MERS-CoV, and SARS-CoV-2.

\begin{tabular}{|c|c|c|c|c|}
\hline $\begin{array}{l}\text { Common Chemokine } \\
\text { Profile }\end{array}$ & $\begin{array}{c}\text { Common Cytokine } \\
\text { Profile }\end{array}$ & $\begin{array}{c}\text { Important Chemokine/Cytokine } \\
\text { Involved in Disease Pathogenesis } \\
\text { (Particularly in Severely Infected Cases) }\end{array}$ & $\begin{array}{c}\text { Role of the Most Prominent Chemokine/Cytokine } \\
\text { in Disease Pathogenesis }\end{array}$ & $\begin{array}{l}\text { Drugs Targeting Chemokines } \\
\text { and Cytokines }\end{array}$ \\
\hline \multicolumn{5}{|c|}{ SARS-CoV } \\
\hline $\begin{array}{l}\text { CCL2, CCL3, CCL5, } \\
\text { CCL10, CXCL-8 (IL-8), } \\
\text { CXCL9, and CXCL10 }\end{array}$ & $\begin{array}{l}\text { IL-1 } \beta \text {, IL-2, IL-6, } \\
\text { IL-10, IL-12, TNF- } \alpha \text {, } \\
\text { IFN- } \alpha / \alpha 2, \text { IFN- } \beta 1 \text {, } \\
\text { IFN2, IFN- } \gamma \text {, } \\
\text { and TGF } \beta\end{array}$ & - $\quad$ Dysregulation of IFN ( $\alpha$ and $\gamma$ ) & $\begin{array}{l}\text { - Induces excessive cytokine and chemokine } \\
\text { levels [109]. } \\
\text { - Recruits monocytes, macrophages, dendritic cells, } \\
\text { NK cells, and T-lymphocytes toward interstitial } \\
\text { lung tissue [112]. }\end{array}$ & $\begin{array}{l}\text { - IFN alfacon-1 and steroids at } \\
\text { early stage infection [169-173]. }\end{array}$ \\
\hline \multicolumn{5}{|c|}{ MERS-CoV } \\
\hline \multirow{3}{*}{$\begin{array}{l}\text { CCL-2, CCL-3, CCL-5, } \\
\text { CXCL-8 (IL-8), } \\
\text { and CXCL-10 }\end{array}$} & & - $\quad$ Dysregulation of IFN $(\alpha, \beta \gamma)$ & • $\quad$ Develops early antiviral Th-1 [121]. & $\begin{array}{l}\text { Recombinant IFN } \alpha / \beta \text { and IFN } \\
\text { agonists (e.g., poly(I:C)) and } \\
\text { mycophenolic acid [66,174-180]. }\end{array}$ \\
\hline & $\begin{array}{l}\text { IL-1 } \beta, \text { IL-6, IL-10, } \\
\text { IL-12, IL-13, IL-15, } \\
\text { IL-17, IL-23, TNF- } \alpha \text {, } \\
\text { IFN- } \gamma, \text { IFN- } \alpha 2, \\
\text { and TGF } \beta\end{array}$ & $\begin{array}{l}\text { - Elevation in IL-10 } \\
\text { - Elevation in IL-6 } \\
\text { - Elevation in CXCL10 }\end{array}$ & $\begin{array}{ll}\text { - } & \text { Inhibits IFN- } \gamma \text { production }[121,125] . \\
\text { - } & \text { Reduces CD8+ T-cells proliferation. [121,125] } \\
\text { Increases viral replication }[121,125] .\end{array}$ & \\
\hline & & - $\quad$ Elevation in IL-17 & $\begin{array}{l}\text { - Recruits neutrophils and monocytes }[33,123] \text {. } \\
\text { - Contributes to the release of IL-1 } \beta, \text { IL-6, TNF- } \alpha \text {, } \\
\text { TGF- } \beta, \text { IL-8, and CCL2 }[33,123] \text {. }\end{array}$ & \\
\hline
\end{tabular}


Table 1. Cont.

\begin{tabular}{|c|c|c|c|c|}
\hline $\begin{array}{l}\text { Common Chemokine } \\
\text { Profile }\end{array}$ & $\begin{array}{l}\text { Common Cytokine } \\
\text { Profile }\end{array}$ & $\begin{array}{c}\text { Important Chemokine/Cytokine } \\
\text { Involved in Disease Pathogenesis } \\
\text { (Particularly in Severely Infected Cases) }\end{array}$ & $\begin{array}{l}\text { Role of the Most Prominent Chemokine/Cytokine } \\
\text { in Disease Pathogenesis }\end{array}$ & $\begin{array}{l}\text { Drugs Targeting Chemokines } \\
\text { and Cytokines }\end{array}$ \\
\hline \multicolumn{5}{|c|}{ SARS-CoV-2 } \\
\hline $\begin{array}{l}\text { CCL2, CCL3, CCL4, } \\
\text { CCL7, CCL8, CXCL1, } \\
\text { CXCL2, CXCL-8 (IL-8), } \\
\text { CXCL6, CCL20, } \\
\text { CXCL-10, and CXCL17 }\end{array}$ & $\begin{array}{l}\text { IL-1 } \beta, \text { IL-2, IL-6, IL-7, } \\
\text { IL-10, IL-17, IL-33, } \\
\text { IFN- }- \text {, TNF- } \alpha \\
\text { and TGF } \beta\end{array}$ & $\begin{array}{l}\text { Upregulation of IFN signaling pathway, but } \\
\text { downregulation of IFN levels }\end{array}$ & $\begin{array}{l}\text { - Contributes to the release of VEGF, CCL2, IL-8 } \\
\text { and additional IL-6 [138]. } \\
\text { Decreases E-cadherin expression on endothelial } \\
\text { cells, leading, together with VEGF, to an increase } \\
\text { in vascular permeability and leakage, } \\
\text { hypotension, and pulmonary dysfunction [138]. } \\
\text { Inhibits HLA-DR expression on CD14 monocytes, } \\
\text { leading to defective lymphoid function [141]. } \\
\text { Impairs the cytotoxic function of NK } \\
\text { cells [143,144]. } \\
\text { Increases CRP, serum amyloid A, fibrinogen, and } \\
\text { hepcidin and inhibits albumin synthesis [138]. } \\
\text { - } \quad \text { Increases ISGs and IFITMs, which inhibit the } \\
\text { cellular entry of the virus [131,149,150]. } \\
\text { - } \quad \text { Induces the release of G-CSF responsible for } \\
\text { - } \quad \text { Contributes to pulmonary edema by inducing the } \\
\text { release of metalloproteinases responsible for } \\
\text { tissue damage and remodeling [158]. } \\
\text { Induces IL-1 } \beta, \text { IL-6, and TNF } \alpha, \text { which collectively } \\
\text { cause systemic inflammatory response [158]. } \\
\text { Induces the release of CXCL1, CXCL2, IL-8, } \\
\text { CXCL10, and CCL20, which recruit more } \\
\text { immune cells to injured lung [158]. }\end{array}$ & 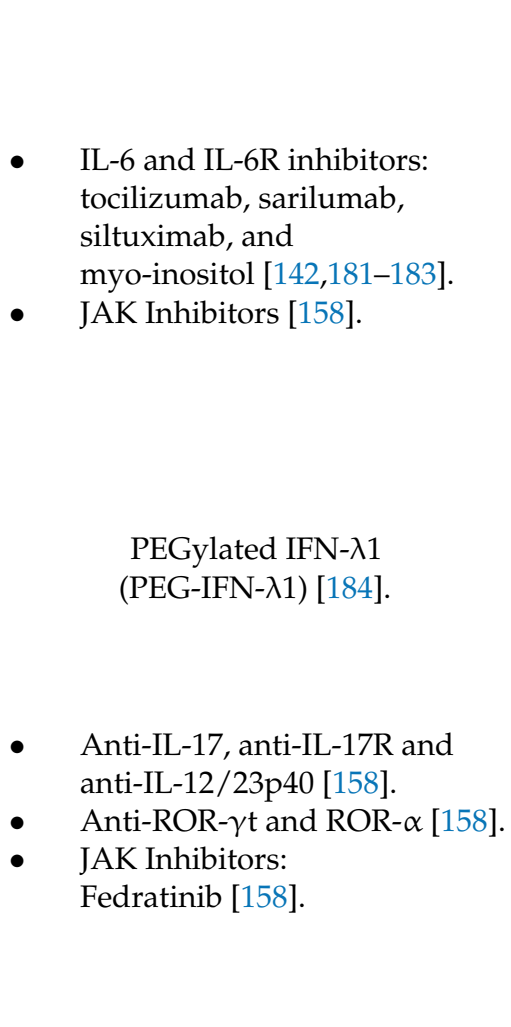 \\
\hline
\end{tabular}


Table 1. Cont.

\begin{tabular}{|c|c|c|c|c|}
\hline $\begin{array}{l}\text { Common Chemokine } \\
\text { Profile }\end{array}$ & $\begin{array}{l}\text { Common Cytokine } \\
\text { Profile }\end{array}$ & $\begin{array}{c}\text { Important Chemokine/Cytokine } \\
\text { Involved in Disease Pathogenesis } \\
\text { (Particularly in Severely Infected Cases) }\end{array}$ & $\begin{array}{l}\text { Role of the Most Prominent Chemokine/Cytokine } \\
\text { in Disease Pathogenesis }\end{array}$ & $\begin{array}{c}\text { Drugs Targeting Chemokines } \\
\text { and Cytokines }\end{array}$ \\
\hline \multicolumn{5}{|c|}{ SARS-CoV-2 } \\
\hline & & Elevation in TNF- $\alpha$ & $\begin{array}{l}\text { Amplifies inflammation by enhancing oxidative } \\
\text { stress and leukocyte adhesion to the epithelium, } \\
\text { modulating blood coagulation and inducing } \\
\text { fever indirectly [162]. }\end{array}$ & $\begin{array}{l}\text { Anti-TNF- } \alpha \text { drugs: } \\
\text { Adalimumab and } \\
\text { infliximab }[185,186] .\end{array}$ \\
\hline & & Elevation in TGF- $\beta$ & $\begin{array}{l}\text { Recruits neutrophils and remodel the airways by } \\
\text { regulating processes used by the virus to develop } \\
\text { pulmonary fibrosis through promoting } \\
\text { myelofibroblast differentiation and } \\
\text { proliferation }[157,159-161] \text {. }\end{array}$ & $\begin{array}{l}\text { - Anti-active TGF- } \beta \text { antibodies } \\
\text { and/or TGF- } \beta \text { inhibitors [159]. }\end{array}$ \\
\hline
\end{tabular}


As demonstrated above, IL-6 is a major cytokine involved in the cytokine storm in COVID-19 patients. Tocilizumab, sarilumab, and siltuximab are different IL-6 antagonists with different pharmacologic properties used efficiently and selectively in the clinic against autoimmune diseases, such as rheumatoid arthritis (RA) and inflammatory conditions, e.g., cytokine-release syndrome [187-189]. The effectiveness of tocilizumab in severe cases of COVID-19 with multi-organ failure was examined in a clinical trial in China. Tocilizumab was found to attenuate the cytokine storm and improve patients' symptoms, such as hypoxemia, lymphopenia, fever, and lung infiltration, without adverse side effects [181]. One of the mechanisms of action of tocilizumab is its ability to restore the expression of HLA-DR on monocytes in COVID-19 patients and reverse the lymphocytopenia as fast as $24 \mathrm{~h}$ of treatment [142]. Another option for treating SARS-CoV-2 infection is antagonists against IL-6 receptors, which can be more effective than IL-6 inhibitors. IL-6 inhibitors can only suppress the cis- and trans-signaling pathways, while IL-6R inhibitors can also suppress trans presentation specific for Th17 cells as an important immune cell contributing to ARDS and helping in ameliorating the cytokine storm in COVID-19 patients [138,190,191]. However, the protective effect of IL-6 antagonists can be argued due to their ability to induce a rapid reduction in IL-10, which is an immunosuppressive cytokine secreted by macrophages, leading to a delay in viral clearance $[138,192]$. This discrepancy in the effect of IL-6 requires further investigation.

Moreover, the current limitations of IL- 6 antagonists are the risk of infections and possible side effects in light of undetermined drug dosage and timing. Therefore, tocilizumab is recommended for use in severely infected patients with high viral load, and not in early disease stages, where it might adversely compromise the effect of IL-6 in viral clearance [182,193]. Another challenge is the compensatory role of other cytokines, such as IL-18, IFN- $\gamma$, and the JAK1 pathway, to regulate macrophage function. Thereby, inhibition of IL-6 alone might not be sufficient to improve patients' conditions, especially since a recent study showed that IL-18 and IFN- $\gamma$ are also among the cytokines elevated in severe COVID-19 patients [194], thus raising the need for combination therapies, which target more than one cytokine at a time. In this regard, more randomized control studies are needed to specify the timing and dosage of IL-6 antagonists, as well as possible drug combinations to reach the best outcome with the lowest side effects.

Aside from IL-6 and IL-6R antagonists, myo-Inositol, a supplement for hormonal regulation that is known to specifically downregulate IL-6 levels and PI3K, which is a key player in the IL-6 signaling pathway, was validated to attenuate the inflammatory pathway in lung disease [195-199]. Because IL-6 is upregulated by hypomethylation in its promoter region, preliminary data indicate that myo-inositol might exert epigenetic effects in targeting this cytokine, hence suggesting that myo-inositol might be beneficial for COVID-19 patients with high IL-6 levels, particularly because it has no adverse side effects compared to IL-6 antagonists $[183,200,201]$.

\subsection{IFNs}

Dysregulation in IFN activity is a common mechanism used by the three $\beta$-CoVs to evade the immune system and cause an uninterrupted increase in viral replication. For this reason, exogenous use of IFN is one treatment option that was tested in both SARS and MERS and recently in COVID-19. In vitro studies showed that IFN- $\beta$ and IFN- $\gamma$ reduced SARS-CoV replication and plaque formation $[169,170]$. Furthermore, a retrospective clinical study and a four-arm trial demonstrated that a combination of IFN alfacon-1 and steroids improved patients' outcomes by reducing lung abnormalities, restoring oxygen saturation level, and normalizing creatinine phosphokinase and lactate dehydrogenase levels [171,172]. However, administration of IFN alfacon-1 and steroids at a late stage of infection proved ineffective, hence stressing the relevance of their combined administration during an early stage of infection [171]. Other retrospective studies showed that interferon alfacon-1 could also be useful if combined with protease inhibitors, together with the viral replication inhibitor, ribavirin, or convalescent plasma-containing neutralizing 
antibodies [173]. Recombinant IFN $\alpha / \beta$ and IFN agonists, alone or in combination with antiviral drugs, were also shown to be effective against MERS-CoV. PEGylated-IFN- $\alpha$ (PEGIFN- $\alpha$ ) decreases viral RNA and cytopathic effect before, during, or after the infection of bronchial epithelial cells with SARS-CoV and MERS-CoV; however, in vitro studies showed that MERS-CoV is $50-100$ times more sensitive to IFN- $\alpha$ than SARS-CoV, due to the absence of ORF6 protein, which blocks IFN-induced nuclear translocation of p-STAT1 [174]. Further, the combination of IFN- $\alpha$ with ribavirin reduced MERS-CoV replication in epithelial cell lines and infected rhesus macaques $[175,176]$. However, two clinical studies reported contradictory results upon testing the combination effect of oral ribavirin and subcutaneous PEG-IFN- $\alpha 2 \mathrm{a}$ in MERS-CoV infected patients [202,203]. On the other hand, IFN- $\beta$ was reported to induce stronger inhibition of MERS-CoV in vitro compared to IFN- $\alpha$ [177]. In addition, animals treated with lopinavir/ritonavir and IFN- $\beta 1 \mathrm{~b}$ exhibited reduced viral load and improvement in the clinical outcomes [178]. Poly(I:C), a strong type I IFN agonist exerting its activity through TLR3 activation was also found to reduce MERS-CoV load and enhance its clearance in BALB/c mice transfected with adenoviral vectors expressing human DPP4 (Ad5-hDPP4) [66]. Moreover, mycophenolic acid, an immunosuppressant commonly used in recipients of organ transplantation, was found to be effective against MERS-CoV in vitro through modulating the expression of ISGs $[177,179,180]$.

Based on the antiviral effects of IFN- $\lambda$ discussed earlier and based on the illustrated research on the use of exogenous IFN in SARS and MERS and on some FDA-approved IFN- $\gamma$ drugs (e.g., Emapalumab) used to treat hemophagocytic lymphohistiocytosis (HLH) and MAS, IFNs are being adopted as an antiviral treatment in COVID-19 patients $[131,143]$ Due to IFNs' protective role, initially, when the viral load is still low, IFNs can be considered as a prophylactic treatment for patients in the early stage of infection, with no signs of inflammatory reaction in the lungs; or in high-risk patients with co-morbidities, being at an increased risk to develop complications [184,204]. Particularly in SARS-CoV-2 infection, the time between first the disease symptoms and ARDS is quite sufficient to allow for this type of intervention as a preventive measure [153].

In comparison with type I IFN, type III IFN- $\lambda$ is more effective and potent to restrict viral replication in the upper respiratory tract, since the receptors for type III IFN- $\lambda$ (IFNLR), in contrast to type I IFN receptors (IFNAR), are not present on immune cells, thus reducing the possible systemic side effects, including inflammation and tissue damage [184,204-207]. The use of IFN- $\lambda$ in SARS-CoV-2 infection is encouraging, since IFN- $\lambda$ enhances the adaptive immune system by stimulating Th1, cytotoxic T cells, and antibody responses required for developing long-term immunity $[208,209]$. Moreover, it was shown that IFN- $\lambda$ is effective on other $\beta-\mathrm{CoVs}$, such as MERS-CoV and SARS-CoV [184]. The only available IFN- $\lambda$ therapeutic agent is PEG-IFN- $\lambda 1$, and it was shown to be safe in lung infections based on 19 clinical studies [184]. Although the use of IFN- $\lambda$ can be promising in COVID-19 patients, extensive research is still needed to investigate several gaps in the biologics of IFNs, especially in the context of SARS-CoV-2. Before trying to use IFN- $\lambda$ as a treatment option, it is important to investigate the following: whether the SARS-CoV-2 induces or blocks the expression of IFN- $\lambda$, whether IFNLR1 is present on alveolar macrophages and endothelial cells, and whether the expression of both IFN- $\lambda$ and its receptors varies with age [184]. Moreover, exogenous IFN- $\lambda$ can be accompanied by adverse events due to the upregulation of IFNLR in the inflamed environment, which exacerbate the inflammatory process, thus raising the need to investigate the expression of IFNLR upon IFN- $\lambda$ treatment and the subsequent responsiveness of immune cells to this stimulation. [210,211]. In contrast to type I IFN, IFN- $\lambda$ facilitates bacterial superinfection by reducing the recruitment of neutrophils and their bactericidal activities, putting this treatment at a disadvantage [212-214].

\subsection{Th17 Blockades}

Several strategies can be used to inhibit Th17 effects in response to SARS-CoV-2, and these include antibodies targeting the cytokines released by Th17, such as the available antiIL-17, anti-IL-17R, and anti-IL-12/23p40, or antibodies targeting the transcription factors 
ROR- $\gamma \mathrm{t}$ and ROR- $\alpha$, which are currently being tested in clinical trials. However, the narrow spectrum and high cost of antibody-based therapy make JAK inhibitors and specifically JAK2 inhibitors that block Th17 a better option to consider for several reasons [158]. First, it is crucial to highlight that the JAK2-STAT3 signaling pathway is downstream to IL-6 and IL-23 cytokines required for Th17 differentiation and function and is also downstream to IL-21, which signals in B-cells, using JAK1 and JAK3 instead of JAK2 [215]. Accordingly, one of the advantages of JAK2 inhibitors, such as Fedratinib, is the selective targeting of IL-6 and IL-23 without compromising the effect of IL-21, as in the case when using STAT3 inhibitors [158]. In the same context, the selectivity of Fedratinib rescues type I IFN, which employs JAK1-STAT1/2 and maintains its antiviral effect [158]. In comparison with IL-6 antagonists whose early administration might compromise the IL-6 effect in viral clearance, the reversibility of JAK2 inhibitors makes using this treatment as a preventive measure possible even before the disease progresses to a severe state and without affecting the needed Th17 immune response in fighting the virus [158]. Another advantage of Fedratinib is that it inhibits the effect of IL-6 on other cell types and the feasibility of using it in combination with other antiviral drugs [158]. Hence, the ability of Fedratinib to target several cytokines with or without other drug combinations pinpoints its promising effects in treating COVID-19 patients.

\subsection{Janus Kinase (JAK) Inhibitors: Baricitinib, Tofacitinib, and Ruxolitinib}

Similar to tocilizumab, JAK inhibitors are approved to treat RA and other inflammatory disorders [216]. JAK inhibitors interfere with the JAK-STAT signaling pathway, which mediates the effect of various cytokines, including IL-2, IL-3, IL-4, IL-5, IL-6, IL-7, IL-9, IL-10, IL-12, IL-15, IL-21, IL-23, and IFN- $(\alpha, \beta$, and $\gamma)$ [217]. The effect of JAK inhibitors on the cytokine storm can be either direct via inhibiting members of the JAK family enzymes (JAK1, JAK2, JAK3, and TYK2) and their downstream signaling or by blocking kinases that regulate endocytosis of SARS-CoV-2 virus, such as AP-2-associated protein kinase 1 (AAK1) and cyclin G-associated kinase (GAK) [218,219]. Ongoing clinical trials to evaluate the effectiveness and efficacy of some JAK inhibitors, such as baricitinib, tofacitinib, and ruxolitinib, are being conducted [219].

\subsection{IL-1 Inhibitors: Anakinra and Colchicine}

As mentioned above, inflammasomes and the pyroptosis process are involved in host immune response against SARS-CoV-2, leading to the release of proinflammatory cytokines, mainly IL-1 $\beta$ and IL-18, which are involved in hematopoiesis and fibrosis. Since IL-1 $\beta$ contributes significantly to the cytokine storm and vascular permeability, and then inhibiting it by anakinra, the approved recombinant antagonist of human IL-1 for RA can be also considered as a treatment regimen in COVID-19 patients [219-221]. A phase-three clinical trial on the effect of anakinra on sepsis and macrophage-activating syndrome (MAS) supports this option to attenuate the cytokine storm post-SARS-CoV-2 infection, especially that patients improved significantly without adverse events [222,223]. Another drug that is known to inhibit the NLRP3 inflammasome is colchicine, which also has a direct effect on TNF- $\alpha$ and IL-6 synthesis and, accordingly, stands to possibly have desirable effects in treating COVID-19 patients [224]. Similar to IL-6 antagonists, the dosage and timing of anakinra and colchicine are yet to be determined by clinical trials to attain optimal effects. Immunosuppressive cytokines IL-37 and IL-38 are also known to inhibit IL-1 $\beta$, IL-6, $\mathrm{TNF}$, and CCL2 by binding to IL-18R $\alpha$ receptors; targeting mTOR; increasing adenosine monophosphate kinase; and inhibiting MHC class II molecule by suppressing MyD88 [225]. These anti-inflammatory cytokines can be potential treatment options for COVID-19.

\subsection{Other Treatments}

Among other cytokine/chemokine-targeting drugs used or in clinical trials to treat COVID-19 is the adjunctive therapy cytosorb, which reduces the circulating levels of cytokines, DAMPs, and PAMPs by absorbing them to treat the cytokine storm [226]. GM-CSF, 
a key molecule in the cytokine storm of COVID-19 patients, can be blocked either by Mavrilimumuab or by JAK inhibitors, since GM-CSF uses JAKs in its signaling pathway $[136,158]$. Further, SAR-CoV-2 infection is associated with the release of reactive oxygen species which activate the NF- $\mathrm{KB}$ and activator protein-1 pathways and induce, as a consequence, the expression of proinflammatory cytokines, such as IL-6, IL-8, and TNF- $\alpha$ [227]. NAcetylcysteine (NAC) is a free-radical scavenger that can aid in inhibiting these cytokines and improving oxidative stress caused by to SARS-CoV-2 infection [228]. Moreover, given the importance of TNF- $\alpha$ in mediating inflammatory reactions by promoting the release of other chemokines and cytokines-and since the levels of TNF- $\alpha$ are shown to be elevated in COVID-19 patients, particularly in severe cases-clinical trials on anti-TNF- $\alpha$ drugs, such as adalimumab and infliximab, are being conducted as a potential option for treatment $[185,186]$. Lastly, recent news from an ongoing clinical trial suggested a breakthrough in COVID-19 management through the use of dexamethasone. Dexamethasone inhibits IL-1 and TNF activity in the lung fibroblasts and thereby reduces lung fibrosis, a common COVID-19 complication [229]. To further elucidate the mechanism of action of dexamethasone in treating SARS-CoV-2, a study revealed that, by using a single-cell atlas, single RNA sequencing, and plasma proteomics, dexamethasone affected circulating neutrophils, altered IFN ${ }^{\text {active }}$ neutrophils, downregulated interferon-stimulated genes, and activated IL-1R2 ${ }^{+}$neutrophils [230]. This will help in controlling COVID-19-associated ARDS characterized by the expansion of distinct neutrophil states characterized by IFN and prostaglandin signaling. Interestingly, males having a higher proportion of IFN ${ }^{\text {active }}$ neutrophils can benefit from the steroid-induced immature neutrophil expansion [230]. This study highlights the effect of gender difference on SARS-CoV-2 infection, outcome, and treatment choice.

\section{Conclusions}

SARS-CoV-2 shares structural features and viral behavior with SARS-CoV and MERS$\mathrm{CoV}$, yet SARS-CoV-2 has a higher transmission rate and more virulence properties as compared to other $\beta$-CoVs. The lack of knowledge regarding SARS-CoV-2 virology and host immune responses promoted an urgent need for prophylactic treatment options to manage infected individuals, especially those at risk of developing severe complications. Chemokines and cytokines play a major role in COVID-19 immunopathology, as they are the underlying cause for exacerbated immune response, leading to cytokine storm, ARDS, multiple-organ failure, and eventually death.

This extensive and up-to-date literature review regarding SARS-CoV-2 immune signature identified several limitations, including variability in laboratory assays used to evaluate cytokine levels, lack of negative control recruitment due to the restrictions imposed by the pandemic, differences in populations demographics, associated co-morbidities or co-infections, and limited study scope to gain a holistic immune profile. Despite these limitations, there is a clear consensus regarding the chemokine and cytokine profile among COVID-19 patients in which IL-6, IFN, CXCL10, IL-17, TGF- $\beta$, and TNF- $\alpha$ are major contributors to the pulmonary immunopathology post-SARS-CoV-2 infection and stand to be important targets for therapy. The importance of inflammatory mediators' crosstalk should also be considered, especially when using drug combinations, in order not to compromise beneficial host immune responses. Furthermore, the host immune profile should serve as the basis for optimum disease management and drug design.

Fine-tuning of cytokines' and chemokines' release is crucial to clear the infection without progressing to organ dysfunctions and death. Based on reviewing the treatment modalities used to manage SARS, MERS, and COVID-19, this review recommends the use of immunosuppression cocktails, provided that patients are closely monitored and continuously assessed to maintain the desirable effects of cytokines and chemokines needed to fight the virus. Finally, more clinical trials are needed to determine the optimal and effective dosage and timing for a therapeutic regimen, as this is lacking for most clinically used drugs. 
Author Contributions: Literature review and data analysis, B.A.K., S.B.S., S.G. and B.M.; designed the study and wrote the manuscript, B.A.K., S.B.S., S.G., B.M., R.H., A.A.M., B.A.-O. and M.T.A.B.; contributed to scientific discussion and manuscript editing, B.A.K., S.B.S., S.G., B.M., R.H., A.A.M., H.A., B.A.-O. and M.T.A.B. All authors contributed to the article and approved the submitted version. All authors have read and agreed to the published version of the manuscript.

Funding: This research received no external funding.

Institutional Review Board Statement: Not applicable.

Informed Consent Statement: Not applicable.

Data Availability Statement: Not applicable.

Conflicts of Interest: The authors declare no conflict of interest.

\section{Abbreviations}

AAK1, AP-2 associated protein kinase 1; ACE2, angiotensin converting enzyme 2; Ad5-hDPP4, adenoviral vector 5-human Dipeptidyl peptidase 4; AECs, airway epithelial cells; ALI, acute lung injury; ARDS, acute respiratory distress syndrome; Arg, arginine; BALF, broncho-alveolar lavage fluid; CCL, chemokine (C-C motif) ligand; $C C R$, chemokine (C-C motif) receptor; $C D$, cluster of differentiation; CoVs, coronaviruses; CRP, C-reactive protein; CX3CL, (C-X3-C motif) ligand; CX3CR, (C-X3-C motif) receptor; CXCL, (C-X-C motif) ligand; CXCR, (C-X-C motif) receptor; DAMP, damage-associated molecular damage; DIC, disseminated intravascular coagulation; DMV, double membrane vesicle; DNA, deoxyribonucleic acid; DPP4, dipeptidyl peptidase 4; ELR, glutamic acid/leucine/arginine amino acid motif; Fas, FS-7 associated surface; GAK, G-associated kinase; G-CSF, granulocytecolony-stimulating factor; Glu, glutamic acid; GPCR, G-protein-coupled receptor; h, hour; HLA, human leukocyte antigen; HLH, hemophagocytic lymphohistiocytosis; HR2, hepated repeat-2; ICU, intensive-care unit; IFITMs, interferon-induced transmembrane proteins; IFN, interferon; IFNR, interferon receptor; IHC, immunohistochemistry; IKKe, I kappa B kinase; IL, interleukin; IP-10, interferon-gamma-induced protein-10; IRAK-M, interleukin-1-receptor-associated kinase M; IRF, interferon regulatory factor; ISGs, interferon-stimulating gene; ISH, in situ hybridization; JAK, Janus kinase; LAG-3, lymphocyte activation gene-3; Leu, leucine; MAP, mitogen-activated protein; MAS, macrophage activating syndrome; MCP, monocyte chemoattractant protein; MDA-5, melanoma differentiation-associated protein-5; MERS, Middle East respiratory syndrome; MERS-CoV, Middle East respiratory syndrome coronavirus; MHC, major histocompatibility complex; MIG, monokine induced by gamma interferon; MIP- $1 \alpha$, macrophage inflammatory protein- 1 alpha; mRNA, messenger ribonucleic acid; MyD88, myeloid differentiation factor 88; NAC, N-acetyl cysteine; NF- $\mathrm{B}$, nuclear factor-kappa B; NK, natural killer; NKG2A, natural killer group 2 member A; NLRP3, (NOD)-like receptor protein 3; NS4, non-structural protein 4; ORF, open reading frame; PAMP, pattern-associated molecular pattern; PBMCs, peripheral blood mononuclear cells; PD-1, programmed cell death protein1; PEG-IFN, PEGylated interferon; PI3K, phosphoinositide 3-kinase; PII, pulmonary inflammation index; PLpro-TM, papain-like protease-transmembrane domain; Poly (I:C), polyinosinic:polycytidylic acid; PPAR $\gamma$, peroxisome proliferator activated receptor gamma; PRNT50, plaque reduction neutralization; RA, rheumatoid arthritis; RANTES, regulated upon activation, normal T-cell expressed and secreted; RIG-1, retinoic acid-inducible gene; RLRs, retinoic acid-inducible gene-like receptors; RNA, ribonucleic acid; ROR, retinoic acid receptor-related orphan receptor; SARS, severe acute respiratory syndrome; SARS-CoV, severe acute respiratory syndrome coronavirus; SHP-2, Src homology 2-phosphatase 2; siRNA, small interfering ribonucleic acid; STAT, signal transducer and activator of transcription; STING, stimulator of interferon genes; TACE, tumor necrosis factor alpha converting enzyme; TBK1, TANK-binding kinase 1 ; TGF- $\beta$, transforming growth factor beta; TH, T helper; TLR, Toll-like receptor; TMPRSS2, transmembrane protease serine 2; TNF, tumor necrosis factor; TYK2, tyrosine kinase 2; VEGF, vascular endothelial growth factor; WHO, World Health Organization; BALF; Bronchoalveolar Lavage Fluid. 


\section{References}

1. Zumla, A.; Chan, J.F.W.; Azhar, E.I.; Hui, D.S.C.; Yuen, K.-Y. Coronaviruses-Drug discovery and therapeutic options. Nat. Rev. Drug Discov. 2016, 15, 327-347. [CrossRef]

2. $\quad$ Li, G.; Fan, Y.; Lai, Y.; Han, T.; Li, Z.; Zhou, P.; Pan, P.; Wang, W.; Hu, D.; Liu, X.; et al. Coronavirus infections and immune responses. J. Med. Virol. 2020, 92, 424-432. [CrossRef]

3. Brand, J.M.V.D.; Smits, S.L.; Haagmans, B.L. Pathogenesis of Middle East respiratory syndrome coronavirus. J. Pathol. 2015, 235, 175-184. [CrossRef]

4. Zumla, A.; Hui, D.S.; Perlman, S. Middle East respiratory syndrome. Lancet 2015, 386, 995-1007. [CrossRef]

5. Chan, J.F.-W.; Lau, S.K.P.; To, K.K.W.; Cheng, V.C.C.; Woo, P.C.Y.; Yuen, K.-Y. Middle East Respiratory Syndrome Coronavirus: Another Zoonotic Betacoronavirus Causing SARS-Like Disease. Clin. Microbiol. Rev. 2015, 28, 465-522. [CrossRef]

6. Zaki, A.M.; Van Boheemen, S.; Bestebroer, T.M.; Osterhaus, D.V.M.; Fouchier, R.A.M. Isolation of a Novel Coronavirus from a Man with Pneumonia in Saudi Arabia. N. Engl. J. Med. 2012, 367, 1814-1820. [CrossRef] [PubMed]

7. Zhao, G.-P. SARS molecular epidemiology: A Chinese fairy tale of controlling an emerging zoonotic disease in the genomics era Philos. Trans. R. Soc. B Biol. Sci. 2007, 362, 1063-1081. [CrossRef]

8. Zhong, N.S.; Zheng, B.J.; Li, Y.M.; Poon, L.L.M.; Xie, Z.H.; Chan, K.H.; Li, P.H.; Tan, S.Y.; Chang, Q.; Xie, J.P.; et al. Epidemiology and cause of severe acute respiratory syndrome (SARS) in Guangdong, People's Republic of China, in February, 2003. Lancet 2003, 362, 1353-1358. [CrossRef]

9. WHO. Summary of Probable SARS Cases with Onset of Illness from 1 November 2002 to 31 July 2003. Available online: https://www.who.int/csr/sars/country/table2004_04_21/en/ (accessed on 20 May 2020).

10. WHO. Middle East Respiratory Syndrome Coronavirus (MERS-CoV). Available online: https://www.who.int/emergencies/ mers-cov/en/ (accessed on 19 May 2020)

11. Prete, M.; Favoino, E.; Catacchio, G.; Racanelli, V.; Perosa, F. SARS-CoV-2 Inflammatory Syndrome. Clinical Features and Rationale for Immunological Treatment. Int. J. Mol. Sci. 2020, 21, 3377. [CrossRef] [PubMed]

12. Kanj, S.; Al-Omari, B. Convalescent Plasma Transfusion for the Treatment of COVID-19 in Adults: A Global Perspective. Viruses 2021, 13, 849. [CrossRef]

13. Tay, M.Z.; Poh, C.M.; Rénia, L.; Macary, P.A.; Ng, L.F.P. The trinity of COVID-19: Immunity, inflammation and intervention. Nat. Rev. Immunol. 2020, 20, 363-374. [CrossRef]

14. Jelinek, H.F.; Mousa, M.; Alefishat, E.; Osman, W.; Spence, I.; Bu, D.; Feng, S.F.; Byrd, J.; Magni, P.A.; Sahibzada, S.; et al. Evolution, Ecology, and Zoonotic Transmission of Betacoronaviruses: A Review. Front. Veter. Sci. 2021, 8, 644414. [CrossRef] [PubMed]

15. Jiang, S.; Shi, Z.; Shu, Y.; Song, J.; Gao, G.F.; Tan, W.; Guo, D. A distinct name is needed for the new coronavirus. Lancet 2020, $395,949$. [CrossRef]

16. Anand, K.; Karade, S.; Sen, S.; Gupta, R.M. Coronaviruses: Origin and evolution. Med. J. Armed Forces India 2020, 76, $136-141$. [CrossRef]

17. World Health Organization. Coronavirus Disease (COVID-19) Pandemic. Available online: https://www.who.int/emergencies/ diseases / novel-coronavirus-2019 (accessed on 19 May 2020).

18. Jin, J.M.; Bai, P.; He, W.; Wu, F.; Liu, X.F.; Han, D.M.; Liu, S.; Yang, J.K. Gender Differences in Patients with COVID-19: Focus on Severity and Mortality. Front. Public Health 2020, 8, 152. [CrossRef]

19. Zhao, J.; Zhao, J.; Legge, K.; Perlman, S. Age-related increases in PGD2 expression impair respiratory DC migration, resulting in diminished T cell responses upon respiratory virus infection in mice. J. Clin. Investig. 2011, 121, 4921-4930. [CrossRef]

20. Guan, W.-J.; Ni, Z.-Y.; Hu, Y.; Liang, W.-H.; Ou, C.-Q.; He, J.-X.; Liu, L.; Shan, H.; Lei, C.-L.; Hui, D.S.C.; et al. Clinical Characteristics of Coronavirus Disease 2019 in China. N. Engl. J. Med. 2019, 382, 1708-1720. [CrossRef] [PubMed]

21. Lauer, S.A.; Grantz, K.H.; Bi, Q.; Jones, F.K.; Zheng, Q.; Meredith, H.R.; Azman, A.S.; Reich, N.G.; Lessler, J. The Incubation Period of Coronavirus Disease 2019 (COVID-19) from Publicly Reported Confirmed Cases: Estimation and Application. Ann. Intern. Med. 2020, 172, 577-582. [CrossRef]

22. Li, Q.; Guan, X.; Wu, P.; Wang, X.; Zhou, L.; Tong, Y.; Ren, R.; Leung, K.S.M.; Lau, E.H.Y.; Wong, J.Y.; et al. Early Transmission Dynamics in Wuhan, China, of Novel Coronavirus-Infected Pneumonia. N. Engl. J. Med. 2020, 382, 1199-1207. [CrossRef] [PubMed]

23. Pung, R.; Chiew, C.J.; Young, B.E.; Chin, S.; Chen, M.I.; Clapham, H.E.; Cook, A.R.; Maurer-Stroh, S.; Toh, M.P.H.S.; Poh, C.; et al. Investigation of three clusters of COVID-19 in Singapore: Implications for surveillance and response measures. Lancet 2020, 395 1039-1046. [CrossRef]

24. Kim, J.Y.; Ko, J.-H.; Kim, Y.; Kim, Y.-J.; Kim, J.-M.; Chung, Y.-S.; Kim, H.M.; Han, M.-G.; Kim, S.Y.; Chin, B.S. Viral Load Kinetics of SARS-CoV-2 Infection in First Two Patients in Korea. J. Korean Med. Sci. 2020, 35, e86. [CrossRef] [PubMed]

25. Pan, Y.; Zhang, D.; Yang, P.; Poon, L.L.M.; Wang, Q. Viral load of SARS-CoV-2 in clinical samples. Lancet Infect. Dis. 2020, 20, 411-412. [CrossRef]

26. Zou, L.; Ruan, F.; Huang, M.; Liang, L.; Huang, H.; Hong, Z.; Yu, J.; Kang, M.; Song, Y.; Xia, J.; et al. SARS-CoV-2 Viral Load in Upper Respiratory Specimens of Infected Patients. N. Engl. J. Med. 2020, 382, 1177-1179. [CrossRef]

27. Peiris, J.S.M.; Chu, C.M.; Cheng, V.; Chan, K.; Hung, I.F.N.; Poon, L.; Law, K.; Tang, B.; Hon, T.; Chan, C.; et al. Clinical progression and viral load in a community outbreak of coronavirus-associated SARS pneumonia: A prospective study. Lancet 2003, 361, 1767-1772. [CrossRef] 
28. Wang, D.; Hu, B.; Hu, C.; Zhu, F.; Liu, X.; Zhang, J.; Wang, B.; Xiang, H.; Cheng, Z.; Xiong, Y.; et al. Clinical Characteristics of 138 Hospitalized Patients with 2019 Novel Coronavirus-Infected Pneumonia in Wuhan, China. JAMA 2020, 323, 1061-1069. [CrossRef]

29. Huang, C.; Wang, Y.; Li, X.; Ren, L.; Zhao, J.; Hu, Y.; Zhang, L.; Fan, G.; Xu, J.; Gu, X.; et al. Clinical features of patients infected with 2019 novel coronavirus in Wuhan, China. Lancet 2020, 395, 497-506. [CrossRef]

30. Do Nascimento, I.J.B.; Cacic, N.; Abdulazeem, H.M.; Von Groote, T.C.; Jayarajah, U.; Weerasekara, I.; Esfahani, M.A.; Civile, V.T.; Marusic, A.; Jerončić, A.; et al. Novel Coronavirus Infection (COVID-19) in Humans: A Scoping Review and Meta-Analysis. J. Clin. Med. 2020, 9, 941. [CrossRef]

31. Thachil, J. The versatile heparin in COVID-19. J. Thromb. Haemost. 2020, 18, 1020-1022. [CrossRef]

32. Wu, Z.; McGoogan, J.M. Characteristics of and Important Lessons from the Coronavirus Disease 2019 (COVID-19) Outbreak in China: Summary of a Report of 72314 Cases From the Chinese Center for Disease Control and Prevention. JAMA 2020, 323, 1239-1242. [CrossRef] [PubMed]

33. Mahallawi, W.H.; Khabour, O.F.; Zhang, Q.; Makhdoum, H.M.; Suliman, B.A. MERS-CoV infection in humans is associated with a pro-inflammatory Th1 and Th17 cytokine profile. Cytokine 2018, 104, 8-13. [CrossRef]

34. Wong, C.K.; Lam, C.W.K.; Wu, A.K.L.; Ip, W.K.; Lee, N.L.S.; Chan, I.H.S.; Lit, L.C.W.; Hui, D.S.C.; Chan, M.H.M.; Chung, S.S.C.; et al. Plasma inflammatory cytokines and chemokines in severe acute respiratory syndrome. Clin. Exp. Immunol. 2004, 136, 95-103. [CrossRef]

35. Channappanavar, R.; Perlman, S. Pathogenic human coronavirus infections: Causes and consequences of cytokine storm and immunopathology. Semin. Immunopathol. 2017, 39, 529-539. [CrossRef]

36. Vilček, J.; Feldmann, M. Historical review: Cytokines as therapeutics and targets of therapeutics. Trends Pharmacol. Sci. 2004, 25, 201-209. [CrossRef]

37. Bachelerie, F.; Ben-Baruch, A.; Burkhardt, A.M.; Combadiere, C.; Farber, J.M.; Graham, G.; Horuk, R.; Sparre-Ulrich, A.H.; Locati, M.; Luster, A.D.; et al. Update on the extended family of chemokine receptors and introducing a new nomenclature for atypical chemokine receptors. Pharmacol. Rev. 2014, 66, 1-79. [CrossRef]

38. Legler, D.F.; Thelen, M. Chemokines: Chemistry, Biochemistry and Biological Function. Chim. Int. J. Chem. 2016, 70, 856-859. [CrossRef]

39. Murphy, P.M.; Baggiolini, M.; Charo, I.F.; Hébert, C.A.; Horuk, R.; Matsushima, K.; Miller, L.H.; Oppenheim, J.J.; Power, C.A. International union of pharmacology. XXII. Nomenclature for chemokine receptors. Pharmacol. Rev. 2000, 52, $145-176$.

40. Gasparyan, A.Y.; Ayvazyan, L.; Blackmore, H.; Kitas, G. Writing a narrative biomedical review: Considerations for authors, peer reviewers, and editors. Rheumatol. Int. 2011, 31, 1409-1417. [CrossRef]

41. Fehr, A.R.; Perlman, S. Coronaviruses: An overview of their replication and pathogenesis. Methods Mol. Biol. 2015, 1282, 1-23. [CrossRef]

42. Li, W.; Moore, M.J.; Vasilieva, N.; Sui, J.; Wong, S.K.; Berne, M.A.; Somasundaran, M.; Sullivan, J.L.; Luzuriaga, K.; Greenough, T.C.; et al. Angiotensin-converting enzyme 2 is a functional receptor for the SARS coronavirus. Nature 2003, 426, 450-454. [CrossRef]

43. Li, F.; Berardi, M.; Li, W.; Farzan, M.; Dormitzer, P.R.; Harrison, S.C. Conformational States of the Severe Acute Respiratory Syndrome Coronavirus Spike Protein Ectodomain. J. Virol. 2006, 80, 6794-6800. [CrossRef]

44. Di Mauro, G.; Scavone, C.; Rafaniello, C.; Rossi, F.; Capuano, A. SARS-Cov-2 infection: Response of human immune system and possible implications for the rapid test and treatment. Int. Immunopharmacol. 2020, 84, 106519. [CrossRef] [PubMed]

45. Turner, A.J.; Hiscox, J.; Hooper, N. ACE2: From vasopeptidase to SARS virus receptor. Trends Pharmacol. Sci. 2004, 25, 291-294. [CrossRef]

46. Walls, A.C.; Park, Y.-J.; Tortorici, M.A.; Wall, A.; McGuire, A.T.; Veesler, D. Structure, Function, and Antigenicity of the SARS-CoV-2 Spike Glycoprotein. Cell 2020, 181, 281-292.e286. [CrossRef] [PubMed]

47. Chen, Y.; Guo, Y.; Pan, Y.; Zhao, Z.J. Structure analysis of the receptor binding of 2019-nCoV. Biochem. Biophys. Res. Commun. 2020, 525, 135-140. [CrossRef]

48. Hamming, I.; Timens, W.; Bulthuis, M.L.C.; Lely, A.T.; Navis, G.J.; van Goor, H. Tissue distribution of ACE2 protein, the functional receptor for SARS coronavirus. A first step in understanding SARS pathogenesis. J. Pathol. 2004, 203, 631-637. [CrossRef] [PubMed]

49. Jia, H.P.; Look, D.C.; Shi, L.; Hickey, M.; Pewe, L.; Netland, J.; Farzan, M.; Wohlford-Lenane, C.; Perlman, S.; McCray, P.B., Jr. ACE2 Receptor Expression and Severe Acute Respiratory Syndrome Coronavirus Infection Depend on Differentiation of Human Airway Epithelia. J. Virol. 2005, 79, 14614-14621. [CrossRef] [PubMed]

50. Xu, H.; Zhong, L.; Deng, J.; Peng, J.; Dan, H.; Zeng, X.; Li, T.; Chen, Q. High expression of ACE2 receptor of 2019-nCoV on the epithelial cells of oral mucosa. Int. J. Oral Sci. 2020, 12, 8. [CrossRef] [PubMed]

51. Al Bataineh, M.T.; Henschel, A.; Mousa, M.; Daou, M.; Waasia, F.; Kannout, H.; Khalili, M.; Kayasseh, M.A.; Alkhajeh, A.; Uddin, M.; et al. Gut Microbiota Interplay With COVID-19 Reveals Links to Host Lipid Metabolism Among Middle Eastern Populations. Front. Microbiol. 2021, 12, 12. [CrossRef]

52. Hoffmann, M.; Kleine-Weber, H.; Schroeder, S.; Krüger, N.; Herrler, T.; Erichsen, S.; Schiergens, T.S.; Herrler, G.; Wu, N.-H.; Nitsche, A.; et al. SARS-CoV-2 Cell Entry Depends on ACE2 and TMPRSS2 and Is Blocked by a Clinically Proven Protease Inhibitor. Cell 2020, 181, 271-280.e278. [CrossRef] 
53. Lu, G.; Hu, Y.; Wang, Q.; Qi, J.; Gao, F.; Li, Y.; Zhang, Y.; Zhang, W.; Yuan, Y.; Bao, J. Molecular basis of binding between novel human coronavirus MERS-CoV and its receptor CD26. Nature 2013, 500, 227-231. [CrossRef]

54. Al-Qahtani, A.A.; Lyroni, K.; Aznaourova, M.; Tseliou, M.; Al-Anazi, M.R.; Al-Ahdal, M.; Alkahtani, S.; Sourvinos, G.; Tsatsanis, C. Middle east respiratory syndrome corona virus spike glycoprotein suppresses macrophage responses via DPP4-mediated induction of IRAK-M and PPAR $\gamma$. Oncotarget 2017, 8, 9053-9066. [CrossRef]

55. Coutard, B.; Valle, C.; de Lamballerie, X.; Canard, B.; Seidah, N.; Decroly, E. The spike glycoprotein of the new coronavirus 2019-nCoV contains a furin-like cleavage site absent in CoV of the same clade. Antivir. Res. 2020, 176, 104742. [CrossRef]

56. Leth-Larsen, R.; Zhong, F.; Chow, V.; Holmskov, U.; Lu, J. The SARS coronavirus spike glycoprotein is selectively recognized by lung surfactant protein D and activates macrophages. Immunobiology 2007, 212, 201-211. [CrossRef] [PubMed]

57. Tseng, C.-T.K.; Perrone, L.A.; Zhu, H.; Makino, S.; Peters, C.J. Severe Acute Respiratory Syndrome and the Innate Immune Responses: Modulation of Effector Cell Function without Productive Infection. J. Immunol. 2005, 174, 7977-7985. [CrossRef] [PubMed]

58. Park, M.D. Macrophages: A Trojan horse in COVID-19? Nat. Rev. Immunol. 2020, 20, 351. [CrossRef]

59. Zhou, Y.; Fu, B.; Zheng, X.; Wang, D.; Zhao, C.; Qi, Y.; Sun, R.; Tian, Z.; Xu, X.; Wei, H. Pathogenic T-cells and inflammatory monocytes incite inflammatory storms in severe COVID-19 patients. Natl. Sci. Rev. 2020, 7, 998-1002. [CrossRef]

60. Jeffers, S.A.; Tusell, S.M.; Gillim-Ross, L.; Hemmila, E.M.; Achenbach, J.E.; Babcock, G.J.; Thomas, W.D.; Thackray, L.B.; Young, M.D.; Mason, R.J.; et al. CD209L (L-SIGN) is a receptor for severe acute respiratory syndrome coronavirus. Proc. Natl. Acad. Sci. USA 2004, 101, 15748-15753. [CrossRef] [PubMed]

61. Lau, Y.L.; Peiris, J.S.M.; Law, H.K.W. Role of dendritic cells in SARS coronavirus infection. Hong Kong Med. J. 2012, 18, 28-30. [PubMed]

62. Chu, H.; Zhou, J.; Wong, B.H.-Y.; Li, C.; Cheng, Z.-S.; Lin, X.; Poon, V.K.-M.; Sun, T.; Lau, C.C.-Y.; Chan, J.F.-W.; et al. Productive replication of Middle East respiratory syndrome coronavirus in monocyte-derived dendritic cells modulates innate immune response. Virology 2014, 454, 197-205. [CrossRef] [PubMed]

63. Janice Oh, H.-L.; Ken-En Gan, S.; Bertoletti, A.; Tan, Y.-J. Understanding the T cell immune response in SARS coronavirus infection. Emerg. Microbes Infect. 2012, 1, 1-6. [CrossRef] [PubMed]

64. Li, T.; Qiu, Z.; Zhang, L.; Han, Y.; He, W.; Liu, Z.; Ma, X.; Fan, H.; Lu, W.; Xie, J.; et al. Significant Changes of Peripheral T Lymphocyte Subsets in Patients with Severe Acute Respiratory Syndrome. J. Infect. Dis. 2004, 189, 648-651. [CrossRef] [PubMed]

65. National Research Project for SARS, B.G. The involvement of natural killer cells in the pathogenesis of severe acute respiratory syndrome. Am. J. Clin. Pathol. 2004, 121, 507-511.

66. Zhao, J.; Li, K.; Wohlford-Lenane, C.; Agnihothram, S.S.; Fett, C.; Zhao, J.; Gale, M.J.; Baric, R.S.; Enjuanes, L.; Gallagher, T.; et al. Rapid generation of a mouse model for Middle East respiratory syndrome. Proc. Natl. Acad. Sci. USA 2014, 111, 4970-4975. [CrossRef] [PubMed]

67. Josset, L.; Menachery, V.; Gralinski, L.E.; Agnihothram, S.; Sova, P.; Carter, V.S.; Yount, B.L.; Graham, R.L.; Baric, R.S.; Katze, M.G. Cell Host Response to Infection with Novel Human Coronavirus EMC Predicts Potential Antivirals and Important Differences with SARS Coronavirus. mBio 2013, 4, e00165-13. [CrossRef] [PubMed]

68. Ishii, T.; Ohnuma, K.; Murakami, A.; Takasawa, N.; Kobayashi, S.; Dang, N.H.; Schlossman, S.F.; Morimoto, C. CD26-mediated signaling for T cell activation occurs in lipid rafts through its association with CD45RO. Proc. Natl. Acad. Sci. USA 2001, 98, 12138-12143. [CrossRef]

69. Ying, T.; Li, W.; Dimitrov, D.S. Discovery of T-Cell Infection and Apoptosis by Middle East Respiratory Syndrome Coronavirus. J. Infect. Dis. 2016, 213, 877-879. [CrossRef] [PubMed]

70. Chu, H.; Zhou, J.; Wong, B.H.-Y.; Li, C.; Chan, J.F.-W.; Cheng, Z.-S.; Yang, D.; Wang, D.; Lee, A.C.Y.; Li, C.; et al. Middle East Respiratory Syndrome Coronavirus Efficiently Infects Human Primary T Lymphocytes and Activates the Extrinsic and Intrinsic Apoptosis Pathways. J. Infect. Dis. 2016, 213, 904-914. [CrossRef] [PubMed]

71. Thevarajan, I.; Nguyen, T.H.O.; Koutsakos, M.; Druce, J.; Caly, L.; van de Sandt, C.E.; Jia, X.; Nicholson, S.; Catton, M.; Cowie, B.; et al. Breadth of concomitant immune responses prior to patient recovery: A case report of non-severe COVID-19. Nat. Med. 2020, 26, 453-455. [CrossRef] [PubMed]

72. Leng, Z.; Zhu, R.; Hou, W.; Feng, Y.; Yang, Y.; Han, Q.; Shan, G.; Meng, F.; Du, D.; Wang, S.; et al. Transplantation of ACE2Mesenchymal Stem Cells Improves the Outcome of Patients with COVID-19 Pneumonia. Aging Dis. 2020, 11, 216-228. [CrossRef] [PubMed]

73. Jiang, Y.; Xu, J.; Zhou, C.; Wu, Z.; Zhong, S.; Liu, J.; Luo, W.; Chen, T.; Qin, Q.; Deng, P. Characterization of Cytokine/Chemokine Profiles of Severe Acute Respiratory Syndrome. Am. J. Respir. Crit. Care Med. 2005, 171, 850-857. [CrossRef]

74. Sheng, W.-H.; Chiang, B.-L.; Chang, S.-C.; Ho, H.-N.; Wang, J.-T.; Chen, Y.-C.; Hsiao, C.-H.; Hseuh, P.-R.; Chie, W.-C.; Yang, P.-C. Clinical manifestations and inflammatory cytokine responses in patients with severe acute respiratory syndrome. J. Formos. Med. Assoc. 2005, 104, 715-723. [PubMed]

75. Tang, N.L.-S.; Chan, P.K.-S.; Wong, C.-K.; To, K.-F.; Wu, A.K.-L.; Sung, Y.-M.; Hui, D.S.-C.; Sung, J.J.-Y.; Lam, C.W.-K. Early Enhanced Expression of Interferon-Inducible Protein-10 (CXCL-10) and Other Chemokines Predicts Adverse Outcome in Severe Acute Respiratory Syndrome. Clin. Chem. 2005, 51, 2333-2340. [CrossRef] [PubMed]

76. Theron, M.; Huang, K.-J.; Chen, Y.-W.; Liu, C.-C.; Lei, H.-Y. A probable role for IFN- $\gamma$ in the development of a lung immunopathology in SARS. Cytokine 2005, 32, 30-38. [CrossRef] [PubMed] 
77. Martin, M.; Lefaix, J.-L.; Delanian, S. TGF- $\beta 1$ and radiation fibrosis: A master switch and a specific therapeutic target? Int. J. Radiat. Oncol. Biol. Phys. 2000, 47, 277-290. [CrossRef]

78. Sime, P.J.; Marr, R.A.; Gauldie, D.; Xing, Z.; Hewlett, B.R.; Graham, F.L.; Gauldie, J. Transfer of Tumor Necrosis Factor- $\alpha$ to Rat Lung Induces Severe Pulmonary Inflammation and Patchy Interstitial Fibrogenesis with Induction of Transforming Growth Factor- $\beta 1$ and Myofibroblasts. Am. J. Pathol. 1998, 153, 825-832. [CrossRef]

79. Vermeire, S.; Van Assche, G.; Rutgeerts, P. C-Reactive Protein as a Marker for Inflammatory Bowel Disease. Inflamm. Bowel Dis. 2004, 10, 661-665. [CrossRef] [PubMed]

80. Law, H.K.-W.; Cheung, C.Y.; Ng, H.Y.; Sia, S.F.; Chan, Y.O.; Luk, W.; Nicholls, J.M.; Peiris, J.S.M.; Lau, Y.L. Chemokine upregulation in SARS-coronavirus-infected, monocyte-derived human dendritic cells. Blood 2005, 106, 2366-2374. [CrossRef]

81. Yao, Z.; Zheng, Z.; Wu, K.; Junhua, Z. Immune environment modulation in pneumonia patients caused by coronavirus: SARS-CoV, MERS-CoV and SARS-CoV-2. Aging 2020, 12, 7639-7651. [CrossRef]

82. Cameron, M.J.; Bermejo-Martin, J.F.; Danesh, A.; Muller, M.P.; Kelvin, D.J. Human immunopathogenesis of severe acute respiratory syndrome (SARS). Virus Res. 2008, 133, 13-19. [CrossRef] [PubMed]

83. Chien, J.-Y.; Hsueh, P.-R.; Cheng, W.-C.; Yu, C.-J.; Yang, P.-C. Temporal changes in cytokine/chemokine profiles and pulmonary involvement in severe acute respiratory syndrome. Respirol. 2006, 11, 715-722. [CrossRef]

84. O'Donnell, R.; Tasker, R.; Roe, M.F.E. SARS: Understanding the coronavirus: Apoptosis may explain lymphopenia of SARS. BMJ 2003, 327, 620. [CrossRef]

85. Wang, C.-H.; Liu, C.-Y.; Wan, Y.-L.; Chou, C.-L.; Huang, K.-H.; Lin, H.-C.; Lin, S.-M.; Lin, T.-Y.; Chung, K.F.; Kuo-Hsiung, H. Persistence of lung inflammation and lung cytokines with high-resolution CT abnormalities during recovery from SARS. Respir. Res. 2005, 6, 42. [CrossRef]

86. Zhang, Y.; Li, J.; Zhan, Y.; Wu, L.; Yu, X.; Zhang, W.; Ye, L.; Xu, S.; Sun, R.; Wang, Y.; et al. Analysis of Serum Cytokines in Patients with Severe Acute Respiratory Syndrome. Infect. Immun. 2004, 72, 4410-4415. [CrossRef]

87. Fox, S.W.; Fuller, K.; Bayley, K.E.; Lean, J.M.; Chambers, T.J. TGF- $\beta 1$ and IFN- $\gamma$ Direct Macrophage Activation by TNF- $\alpha$ to Osteoclastic or Cytocidal Phenotype. J. Immunol. 2000, 165, 4957-4963. [CrossRef]

88. Fujiwara, N.; Kobayashi, K. Macrophages in Inflammation. Curr. Drug Targets Inflamm. Allergy 2005, 4, 281-286. [CrossRef]

89. He, L.; Ding, Y.; Zhang, Q.; Che, X.; He, Y.; Shen, H.; Wang, H.; Li, Z.; Zhao, L.; Geng, J.; et al. Expression of elevated levels of pro-inflammatory cytokines in SARS-CoV-infected ACE2+cells in SARS patients: Relation to the acute lung injury and pathogenesis of SARS. J. Pathol. 2006, 210, 288-297. [CrossRef]

90. Chen, R.-F.; Chang, J.-C.; Yeh, W.-T.; Lee, C.-H.; Liu, J.-W.; Eng, H.-L.; Yang, K.D. Role of vascular cell adhesion molecules and leukocyte apoptosis in the lymphopenia and thrombocytopenia of patients with severe acute respiratory syndrome (SARS). Microbes Infect. 2006, 8, 122-127. [CrossRef]

91. Hagimoto, N.; Kuwano, K.; Inoshima, I.; Yoshimi, M.; Nakamura, N.; Fujita, M.; Maeyama, T.; Hara, N. TGF- $\beta 1$ as an Enhancer of Fas-Mediated Apoptosis of Lung Epithelial Cells. J. Immunol. 2002, 168, 6470-6478. [CrossRef] [PubMed]

92. Matute-Bello, G.; Martin, T.R. Science review: Apoptosis in acute lung injury. Crit. Care 2003, 7, 355-358. [CrossRef] [PubMed]

93. Yoshikawa, T.; Hill, T.; Li, K.; Peters, C.J.; Tseng, C.-T.K. Severe Acute Respiratory Syndrome (SARS) Coronavirus-Induced Lung Epithelial Cytokines Exacerbate SARS Pathogenesis by Modulating Intrinsic Functions of Monocyte-Derived Macrophages and Dendritic Cells. J. Virol. 2009, 83, 3039-3048. [CrossRef] [PubMed]

94. Zhu, M. SARS Immunity and Vaccination. Cell. Mol. Immunol. 2004, 1, 193-198.

95. De Lang, A.; Osterhaus, A.; Haagmans, B.L. Interferon- $\gamma$ and interleukin-4 downregulate expression of the SARS coronavirus receptor ACE2 in Vero E6 cells. Virology 2006, 353, 474-481. [CrossRef]

96. Jones, B.M.; Ma, E.S.K.; Peiris, J.S.M.; Wong, P.C.; Ho, J.C.M.; Lam, B.; Lai, K.N.; Tsang, K.W.T. Prolonged disturbances of in vitro cytokine production in patients with severe acute respiratory syndrome (SARS) treated with ribavirin and steroids. Clin. Exp. Immunol. 2004, 135, 467-473. [CrossRef]

97. Li, Z.; Guo, X.; Hao, W.; Wu, Y.; Ji, Y.; Zhao, Y.; Liu, F.; Xie, X. The relationship between serum interleukins and T-lymphocyte subsets in patients with severe acute respiratory syndrome. Chin. Med. J. 2003, 116, 981-984.

98. Cameron, M.J.; Ran, L.; Xu, L.; Danesh, A.; Bermejo-Martin, J.F.; Cameron, C.M.; Muller, M.P.; Gold, W.L.; Richardson, S.E.; Poutanen, S.; et al. Interferon-Mediated Immunopathological Events Are Associated with Atypical Innate and Adaptive Immune Responses in Patients with Severe Acute Respiratory Syndrome. J. Virol. 2007, 81, 8692-8706. [CrossRef]

99. Iwasaki, A.; Pillai, P.S. Innate immunity to influenza virus infection. Nat. Rev. Immunol. 2014, 14, 315-328. [CrossRef]

100. Li, C.K.-F.; Xu, X. Host Immune Responses to SARS Coronavirus in Humans. Mol. Biol. SARS-Coronavirus 2009, $22,259-278$. [CrossRef]

101. Kato, H.; Takeuchi, O.; Sato, S.; Yoneyama, M.; Yamamoto, M.; Matsui, K.; Uematsu, S.; Jung, A.; Kawai, T.; Ishii, K.; et al. Differential roles of MDA5 and RIG-I helicases in the recognition of RNA viruses. Nature 2006, 441, 101-105. [CrossRef]

102. Sato, M.; Suemori, H.; Hata, N.; Asagiri, M.; Ogasawara, K.; Nakao, K.; Nakaya, T.; Katsuki, M.; Noguchi, S.; Tanaka, N.; et al. Distinct and Essential Roles of Transcription Factors IRF-3 and IRF-7 in Response to Viruses for IFN- $\alpha / \beta$ Gene Induction. Immunity 2000, 13, 539-548. [CrossRef]

103. Levy, D.E.; Darnell, J.E., Jr. STATs: Transcriptional control and biological impact. Nat. Rev. Mol. Cell Biol. 2002, 3, 651-662. [CrossRef] [PubMed] 
104. Snijder, E.J.; van der Meer, Y.; Zevenhoven-Dobbe, J.; Onderwater, J.J.M.; van der Meulen, J.; Koerten, H.K.; Mommaas, A.M. Ultrastructure and Origin of Membrane Vesicles Associated with the Severe Acute Respiratory Syndrome Coronavirus Replication Complex. J. Virol. 2006, 80, 5927-5940. [CrossRef]

105. Versteeg, G.; Bredenbeek, P.J.; Worm, S.H.V.D.; Spaan, W.J. Group 2 coronaviruses prevent immediate early interferon induction by protection of viral RNA from host cell recognition. Virology 2007, 361, 18-26. [CrossRef] [PubMed]

106. Kopecky-Bromberg, S.A.; Martínez-Sobrido, L.; Frieman, M.; Baric, R.A.; Palese, P. Severe Acute Respiratory Syndrome Coronavirus Open Reading Frame (ORF) 3b, ORF 6, and Nucleocapsid Proteins Function as Interferon Antagonists. J. Virol. 2007, 81, 548-557. [CrossRef]

107. Frieman, M.; Yount, B.; Heise, M.; Kopecky-Bromberg, S.A.; Palese, P.; Baric, R.S. SARS-CoV ORF6 antagonizes STAT1 function by sequestering nuclear import factors on the rER/Golgi membrane. J. Virol. 2007, 81, 9812-9824. [CrossRef]

108. Chen, X.; Yang, X.; Zheng, Y.; Yang, Y.; Xing, Y.; Chen, Z. SARS coronavirus papain-like protease inhibits the type I interferon signaling pathway through interaction with the STING-TRAF3-TBK1 complex. Protein Cell 2014, 5, 369-381. [CrossRef]

109. Channappanavar, R.; Fehr, A.; Vijay, R.; Mack, M.; Zhao, J.; Meyerholz, D.; Perlman, S. Dysregulated Type I Interferon and Inflammatory Monocyte-Macrophage Responses Cause Lethal Pneumonia in SARS-CoV-Infected Mice. Cell Host Microbe 2016, 19, 181-193. [CrossRef]

110. Teijaro, J.R.; Ng, C.; Lee, A.M.; Sullivan, B.M.; Sheehan, K.C.F.; Welch, M.; Schreiber, R.D.; De La Torre, J.C.; Oldstone, M.B.A. Persistent LCMV Infection Is Controlled by Blockade of Type I Interferon Signaling. Science 2013, 340, 207-211. [CrossRef] [PubMed]

111. Tokunaga, R.; Zhang, W.; Naseem, M.; Puccini, A.; Berger, M.D.; Soni, S.; McSkane, M.; Baba, H.; Lenz, H.-J. CXCL9, CXCL10, CXCL11/CXCR3 axis for immune activation-A target for novel cancer therapy. Cancer Treat. Rev. 2018, 63, 40-47. [CrossRef]

112. Agostini, C.; Facco, M.; Siviero, M.; Carollo, D.; Galvan, S.; Cattelan, A.M.; Zambello, R.; Trentin, L.; Semenzato, G. CXC chemokines IP-10 and mig expression and direct migration of pulmonary CD8+/CXCR3+ T cells in the lungs of patients with HIV infection and T-cell alveolitis. Am. J. Respir. Crit. Care Med. 2000, 162, 1466-1473. [CrossRef] [PubMed]

113. Lau, S.K.P.; Lau, C.C.Y.; Chan, K.-H.; Li, C.P.Y.; Chen, H.; Jin, D.-Y.; Chan, J.F.-W.; Woo, P.C.Y.; Yuen, K.-Y. Delayed induction of proinflammatory cytokines and suppression of innate antiviral response by the novel Middle East respiratory syndrome coronavirus: Implications for pathogenesis and treatment. J. Gen. Virol. 2013, 94, 2679-2690. [CrossRef]

114. Hammond, M.E.; Lapointe, G.R.; Feucht, P.H.; Hilt, S.; Gallegos, C.A.; Gordon, C.A.; Giedlin, M.A.; Mullenbach, G.; TekampOlson, P. IL-8 induces neutrophil chemotaxis predominantly via type I IL-8 receptors. J. Immunol. 1995, 155, $1428-1433$.

115. Reghunathan, R.; Jayapal, M.; Hsu, L.-Y.; Chng, H.-H.; Tai, D.; Leung, B.P.; Melendez, A.J. Expression profile of immune response genes in patients with Severe Acute Respiratory Syndrome. BMC Immunol. 2005, 6, 2. [CrossRef] [PubMed]

116. Dinarello, C.A. The biological properties of interleukin-1. Eur. Cytokine Netw. 1994, 5, 517-531.

117. Zhou, J.; Chu, H.; Li, C.; Wong, B.H.-Y.; Cheng, Z.-S.; Poon, V.K.-M.; Sun, T.; Lau, C.C.-Y.; Wong, K.K.-Y.; Chan, J.Y.-W.; et al. Active Replication of Middle East Respiratory Syndrome Coronavirus and Aberrant Induction of Inflammatory Cytokines and Chemokines in Human Macrophages: Implications for Pathogenesis. J. Infect. Dis. 2014, 209, 1331-1342. [CrossRef] [PubMed]

118. De Wit, E.; Rasmussen, A.L.; Falzarano, D.; Bushmaker, T.; Feldmann, F.; Brining, D.L.; Fischer, E.R.; Martellaro, C.; Okumura, A.; Chang, J. Middle East respiratory syndrome coronavirus (MERS-CoV) causes transient lower respiratory tract infection in rhesus macaques. Proc. Natl. Acad. Sci. USA 2013, 110, 16598-16603. [CrossRef]

119. Kim, E.S.; Choe, P.G.; Park, W.B.; Oh, H.S.; Kim, E.J.; Nam, E.Y.; Na, S.H.; Kim, M.; Song, K.-H.; Bang, J.H.; et al. Clinical Progression and Cytokine Profiles of Middle East Respiratory Syndrome Coronavirus Infection. J. Korean Med. Sci. 2016, 31, 1717-1725. [CrossRef]

120. Chan, R.W.Y.; Chan, M.C.W.; Agnihothram, S.; Chan, L.L.Y.; Kuok, D.I.T.; Fong, J.H.M.; Guan, Y.; Poon, L.; Baric, R.S.; Nicholls, J.M.; et al. Tropism of and Innate Immune Responses to the Novel Human Betacoronavirus Lineage C Virus in Human Ex Vivo Respiratory Organ Cultures. J. Virol. 2013, 87, 6604-6614. [CrossRef] [PubMed]

121. Faure, E.; Poissy, J.; Goffard, A.; Fournier, C.; Kipnis, E.; Titecat, M.; Bortolotti, P.; Martinez, L.; Dubucquoi, S.; Dessein, R.; et al. Distinct Immune Response in Two MERS-CoV-Infected Patients: Can We Go from Bench to Bedside? PLoS ONE 2014, 9 , e88716. [CrossRef] [PubMed]

122. Da Guan, W.; Mok, C.K.P.; Chen, Z.L.; Feng, L.Q.; Li, Z.T.; Huang, J.C.; Ke, C.W.; Deng, X.; Ling, Y.; Wu, S.G.; et al. Characteristics of Traveler with Middle East Respiratory Syndrome, China, 2015. Emerg. Infect. Dis. 2015, 21, 2278-2280. [CrossRef]

123. Jin, W.; Dong, C. IL-17 cytokines in immunity and inflammation. Emerg. Microbes Infect. 2013, 2, 1-5. [CrossRef]

124. Ng, D.L.; Al Hosani, F.; Keating, M.K.; Gerber, S.I.; Jones, T.L.; Metcalfe, M.G.; Tong, S.; Tao, Y.; Alami, N.N.; Haynes, L.M.; et al. Clinicopathologic, Immunohistochemical, and Ultrastructural Findings of a Fatal Case of Middle East Respiratory Syndrome Coronavirus Infection in the United Arab Emirates, April 2014. Am. J. Pathol. 2016, 186, 652-658. [CrossRef] [PubMed]

125. Sabat, R. IL-10 family of cytokines. Cytokine Growth Factor Rev. 2010, 21, 315-324. [CrossRef]

126. Chen, I.-Y.; Moriyama, M.; Chang, M.-F.; Ichinohe, T. Severe Acute Respiratory Syndrome Coronavirus Viroporin 3a Activates the NLRP3 Inflammasome. Front. Microbiol. 2019, 10, 50. [CrossRef] [PubMed]

127. Fink, S.L.; Cookson, B.T. Apoptosis, Pyroptosis, and Necrosis: Mechanistic Description of Dead and Dying Eukaryotic Cells. Infect. Immun. 2005, 73, 1907-1916. [CrossRef]

128. Huang, K.-J.; Su, I.-J.; Theron, M.; Wu, Y.-C.; Lai, S.-K.; Liu, C.-C.; Lei, H.-Y. An interferon- $\gamma$-related cytokine storm in SARS patients. J. Med. Virol. 2005, 75, 185-194. [CrossRef] [PubMed] 
129. Prompetchara, E.; Ketloy, C.; Palaga, T. Immune responses in COVID-19 and potential vaccines: Lessons learned from SARS and MERS epidemic. Asian Pac. J. Allergy Immunol. 2020, 38, 1-9. [CrossRef]

130. Xiong, Y.; Liu, Y.; Cao, L.; Wang, D.; Guo, M.; Jiang, A.; Guo, D.; Hu, W.; Yang, J.; Tang, Z.; et al. Transcriptomic characteristics of bronchoalveolar lavage fluid and peripheral blood mononuclear cells in COVID-19 patients. Emerg. Microbes Infect. 2020, 9 , 761-770. [CrossRef]

131. Zhou, Z.; Ren, L.; Zhang, L.; Zhong, J.; Xiao, Y.; Jia, Z.; Guo, L.; Yang, J.; Wang, C.; Jiang, S.; et al. Heightened Innate Immune Responses in the Respiratory Tract of COVID-19 Patients. Cell Host Microbe 2020, 27, 883-890.e882. [CrossRef] [PubMed]

132. Donnelly, S.; Haslett, C.; Strieter, R.M.; Kunkel, S.L.; Walz, A.; Robertson, C.R.; Carter, D.C.; Pollok, A.J.; Grant, I.S. Interleukin-8 and development of adult respiratory distress syndrome in at-risk patient groups. Lancet 1993, 341, 643-647. [CrossRef]

133. Frevert, C.W.; Huang, S.; Danaee, H.; Paulauskis, J.D.; Kobzik, L. Functional characterization of the rat chemokine KC and its importance in neutrophil recruitment in a rat model of pulmonary inflammation. J. Immunol. 1995, 154, 335-344.

134. Miller, E.J.; Cohen, A.B.; Nagao, S.; Griffith, D.; Maunder, R.J.; Martin, T.R.; Weiner-Kronish, J.P.; Sticherling, M.; Christophers, E.; Matthay, M.A. Elevated Levels of NAP-1/Interleukin-8 Are Present in the Airspaces of Patients with the Adult Respiratory Distress Syndrome and Are Associated with Increased Mortality. Am. Rev. Respir. Dis. 1992, 146, 427-432. [CrossRef]

135. Angioni, R.; Sánchez-Rodríguez, R.; Munari, F.; Bertoldi, N.; Arcidiacono, D.; Cavinato, S.; Marturano, D.; Zaramella, A.; Realdon, S.; Cattelan, A.; et al. Age-severity matched cytokine profiling reveals specific signatures in COVID-19 patients. Cell Death Dis. 2020, 11, 957. [CrossRef] [PubMed]

136. Zhou, Y.; Fu, B.; Zheng, X.; Wang, D.; Zhao, C.; Qi, Y.; Sun, R.; Tian, Z.; Xu, X.; Wei, H. Aberrant pathogenic GM-CSF ${ }^{+}$T cells and inflammatory CD14 ${ }^{+} \mathrm{CD} 16^{+}$monocytes in severe pulmonary syndrome patients of a new coronavirus. bioRxiv 2020. [CrossRef]

137. Moore, B.J.B.; June, C.H. Cytokine release syndrome in severe COVID-19. Science 2020, 368, 473-474. [CrossRef]

138. Tanaka, T.; Narazaki, M.; Kishimoto, T. Immunotherapeutic implications of IL-6 blockade for cytokine storm. Immunotherapy 2016, 8, 959-970. [CrossRef] [PubMed]

139. Aziz, M.; Fatima, R.; Assaly, R. Elevated interleukin-6 and severe COVID-19: A meta-analysis. J. Med. Virol. 2020, 92, 2283-2285. [CrossRef] [PubMed]

140. Wan, S.; Yi, Q.; Fan, S.; Lv, J.; Zhang, X.; Guo, L.; Lang, C.; Xiao, Q.; Xiao, K.; Yi, Z.; et al. Relationships among lymphocyte subsets, cytokines, and the pulmonary inflammation index in coronavirus (COVID-19) infected patients. Br. J. Haematol. 2020, 189, 428-437. [CrossRef] [PubMed]

141. Ohno, Y.; Kitamura, H.; Takahashi, N.; Ohtake, J.; Kaneumi, S.; Sumida, K.; Homma, S.; Kawamura, H.; Minagawa, N.; Shibasaki, S.; et al. IL-6 down-regulates HLA class II expression and IL-12 production of human dendritic cells to impair activation of antigen-specific CD4+ T cells. Cancer Immunol. Immunother. 2016, 65, 193-204. [CrossRef]

142. Giamarellos-Bourboulis, E.J.; Netea, M.G.; Rovina, N.; Akinosoglou, K.; Antoniadou, A.; Antonakos, N.; Damoraki, G.; Gkavogianni, T.; Adami, M.-E.; Katsaounou, P.; et al. Complex Immune Dysregulation in COVID-19 Patients with Severe Respiratory Failure. Cell Host Microbe 2020, 27, 992-1000.e3. [CrossRef]

143. Henderson, L.A.; Canna, S.W.; Schulert, G.S.; Volpi, S.; Lee, P.Y.; Kernan, K.F.; Caricchio, R.; Mahmud, S.; Hazen, M.M.; Halyabar, O.; et al. On the Alert for Cytokine Storm: Immunopathology in COVID-19. Arthritis Rheumatol. 2020, 72, 1059-1063. [CrossRef]

144. Cifaldi, L.; Prencipe, G.; Caiello, I.; Bracaglia, C.; Locatelli, F.; De Benedetti, F.; Strippoli, R. Inhibition of Natural Killer Cell Cytotoxicity by Interleukin-6: Implications for the Pathogenesis of Macrophage Activation Syndrome. Arthritis Rheumatol. 2015, 67, 3037-3046. [CrossRef]

145. Park, A.; Iwasaki, A. Type I and Type III Interferons-Induction, Signaling, Evasion, and Application to Combat COVID-19. Cell Host Microbe 2020, 27, 870-878. [CrossRef]

146. Schoggins, J.W.; Rice, C.M. Interferon-stimulated genes and their antiviral effector functions. Curr. Opin. Virol. 2011, 1, 519-525. [CrossRef]

147. Kotenko, S.V.; Rivera, A.; Parker, D.; Durbin, J.E. Type III IFNs: Beyond antiviral protection. Semin. Immunol. $2019,43,101303$. [CrossRef] [PubMed]

148. Smits, S.L.; De Lang, A.; Brand, J.M.A.V.D.; Leijten, L.M.; van Ijcken, W.; Eijkemans, M.J.C.; Van Amerongen, G.; Kuiken, T.; Andeweg, A.C.; Osterhaus, A.; et al. Exacerbated Innate Host Response to SARS-CoV in Aged Non-Human Primates. PLoS Pathog. 2010, 6, e1000756. [CrossRef] [PubMed]

149. Huang, I.-C.; Bailey, C.C.; Weyer, J.L.; Radoshitzky, S.; Becker, M.M.; Chiang, J.J.; Brass, A.L.; Ahmed, A.A.; Chi, X.; Dong, L.; et al. Distinct Patterns of IFITM-Mediated Restriction of Filoviruses, SARS Coronavirus, and Influenza A Virus. PLOS Pathog. 2011, 7, e1001258. [CrossRef]

150. Wrensch, F.; Winkler, M.; Pöhlmann, S. IFITM Proteins Inhibit Entry Driven by the MERS-Coronavirus Spike Protein: Evidence for Cholesterol-Independent Mechanisms. Viruses 2014, 6, 3683-3698. [CrossRef] [PubMed]

151. Blanco-Melo, D.; Nilsson-Payant, B.E.; Liu, W.-C.; Uhl, S.; Hoagland, D.; Møller, R.; Jordan, T.X.; Oishi, K.; Panis, M.; Sachs, D.; et al. Imbalanced Host Response to SARS-CoV-2 Drives Development of COVID-19. Cell 2020, 181, 1036-1045.e1039. [CrossRef] [PubMed]

152. Wei, L.; Ming, S.; Zou, B.; Wu, Y.; Hong, Z.; Li, Z.; Zheng, X.; Huang, M.; Luo, L.; Liang, J.; et al. Viral Invasion and Type I Interferon Response Characterize the Immunophenotypes during COVID-19 Infection. SSRN Electron. J. 2020. [CrossRef]

153. Andreakos, E.; Tsiodras, S. COVID-19: Lambda interferon against viral load and hyperinflammation. EMBO Mol. Med. 2020, 12. [CrossRef] 
154. Comar, C.E.; Goldstein, S.A.; Li, Y.; Yount, B.; Baric, R.S.; Weiss, S.R. Antagonism of dsRNA-Induced Innate Immune Pathways by NS4a and NS4b Accessory Proteins during MERS Coronavirus Infection. mBio 2019, 10, e00319-19. [CrossRef]

155. Lokugamage, K.G.; Schindewolf, C.; Menachery, V.D. SARS-CoV-2 sensitive to type I interferon pretreatment. bioRxiv 2020. [CrossRef]

156. Chen, J.; Subbarao, K. The Immunobiology of SARS. Annu. Rev. Immunol. 2007, 25, 443-472. [CrossRef]

157. Xu, Z.; Shi, L.; Wang, Y.; Zhang, J.; Huang, L.; Zhang, C.; Liu, S.; Zhao, P.; Liu, H.; Zhu, L.; et al. Pathological findings of COVID-19 associated with acute respiratory distress syndrome. Lancet Respir. Med. 2020, 8, 420-422. [CrossRef]

158. Wu, D.; Yang, X.O. TH17 responses in cytokine storm of COVID-19: An emerging target of JAK2 inhibitor Fedratinib. J. Microbiol. Immunol. Infect. 2020, 53, 368-370. [CrossRef] [PubMed]

159. Chen, W. A potential treatment of COVID-19 with TGF- $\beta$ blockade. Int. J. Biol. Sci. 2020, 16, 1954-1955. [CrossRef] [PubMed]

160. Saxena, V.; Lienesch, D.W.; Zhou, M.; Bommireddy, R.; Azhar, M.; Doetschman, T.; Singh, R.R. Dual Roles of Immunoregulatory Cytokine TGF- $\beta$ in the Pathogenesis of Autoimmunity-Mediated Organ Damage. J. Immunol. 2008, 180, 1903-1912. [CrossRef]

161. Yu, X.; Buttgereit, A.; Lelios, I.; Utz, S.G.; Cansever, D.; Becher, B.; Greter, M. The Cytokine TGF- $\beta$ Promotes the Development and Homeostasis of Alveolar Macrophages. Immunity 2017, 47, 903-912.e904. [CrossRef]

162. Zelová, H.; Hošek, J. TNF- $\alpha$ signalling and inflammation: Interactions between old acquaintances. Inflamm. Res. 2013, 62, 641-651. [CrossRef]

163. Haga, S.; Yamamoto, N.; Nakai-Murakami, C.; Osawa, Y.; Tokunaga, K.; Sata, T.; Yamamoto, N.; Sasazuki, T.; Ishizaka, Y. Modulation of TNF- -converting enzyme by the spike protein of SARS-CoV and ACE2 induces TNF- production and facilitates viral entry. Proc. Natl. Acad. Sci. USA 2008, 105, 7809-7814. [CrossRef]

164. Yang, Y.; Shen, C.; Li, J.; Yuan, J.; Wei, J.; Huang, F.; Wang, F.; Li, G.; Li, Y.; Xing, L.; et al. Plasma IP-10 and MCP-3 levels are highly associated with disease severity and predict the progression of COVID-19. J. Allergy Clin. Immunol. 2020, 146, 119-127.e4. [CrossRef] [PubMed]

165. Ichikawa, A.; Kuba, K.; Morita, M.; Chida, S.; Tezuka, H.; Hara, H.; Sasaki, T.; Ohteki, T.; Ranieri, V.M.; Dos Santos, C.C.; et al. CXCL10-CXCR3 Enhances the Development of Neutrophil-mediated Fulminant Lung Injury of Viral and Nonviral Origin. Am. J. Respir. Crit. Care Med. 2013, 187, 65-77. [CrossRef] [PubMed]

166. Phan, T. Genetic diversity and evolution of SARS-CoV-2. Infect. Genet. Evol. 2020, 81, 104260. [CrossRef] [PubMed]

167. Lagunas-Rangel, F.A.; Chávez-Valencia, V. High IL-6/IFN- $\gamma$ ratio could be associated with severe disease in COVID-19 patients. J. Med. Virol. 2020, 92, 1789-1790. [CrossRef] [PubMed]

168. McLoughlin, R.; Witowski, J.; Robson, R.L.; Wilkinson, T.; Hurst, S.M.; Williams, A.S.; Williams, J.D.; Rose-John, S.; Jones, S.A.; Topley, N. Interplay between IFN- $\gamma$ and IL-6 signaling governs neutrophil trafficking and apoptosis during acute inflammation. $J$. Clin. Investig. 2003, 112, 598-607. [CrossRef]

169. Cinatl, J.; Morgenstern, B.; Bauer, G.; Chandra, P.; Rabenau, H.; Doerr, H. Treatment of SARS with human interferons. Lancet 2003, 362, 293-294. [CrossRef]

170. Sainz, B., Jr.; Mossel, E.C.; Peters, C.J.; Garry, R.F. Interferon-beta and interferon-gamma synergistically inhibit the replication of severe acute respiratory syndrome-associated coronavirus (SARS-CoV). Virology 2004, 329, 11-17. [CrossRef]

171. Loutfy, M.R.; Blatt, L.M.; Siminovitch, K.A.; Ward, S.; Wolff, B.; Lho, H.; Pham, D.H.; Deif, H.; LaMere, E.A.; Chang, M.; et al. Interferon Alfacon-1 Plus Corticosteroids in Severe Acute Respiratory Syndrome: A Preliminary Study. JAMA 2003, 290, 3222-3228. [CrossRef] [PubMed]

172. Zhao, Z.; Zhang, F.; Xu, M.; Huang, K.; Zhong, W.; Cai, W.; Yin, Z.; Huang, S.; Deng, Z.; Wei, M.; et al. Description and clinical treatment of an early outbreak of severe acute respiratory syndrome (SARS) in Guangzhou, PR China. J. Med. Microbiol. 2003, 52, 715-720. [CrossRef]

173. Wong, S.S.Y.; Yuen, K.-Y. The management of coronavirus infections with particular reference to SARS. J. Antimicrob. Chemother. 2008, 62, 437-441. [CrossRef]

174. De Wilde, A.H.; Raj, V.S.; Oudshoorn, D.; Bestebroer, T.M.; Van Nieuwkoop, S.; Limpens, R.W.A.L.; Posthuma, C.C.; Van Der Meer, Y.; Barcena, M.; Haagmans, B.L.; et al. MERS-coronavirus replication induces severe in vitro cytopathology and is strongly inhibited by cyclosporin A or interferon- $\alpha$ treatment. J. Gen. Virol. 2013, 94, 1749-1760. [CrossRef]

175. Falzarano, D.; de Wit, E.; Rasmussen, A.; Feldmann, F.; Okumura, A.; Scott, D.P.; Brining, D.; Bushmaker, T.; Martellaro, C.; Baseler, L.; et al. Treatment with interferon- $\alpha 2 b$ and ribavirin improves outcome in MERS-CoV-infected rhesus macaques. Nat. Med. 2013, 19, 1313-1317. [CrossRef]

176. Falzarano, D.; de Wit, E.; Martellaro, C.; Callison, J.; Munster, V.; Feldmann, H. Inhibition of novel $\beta$ coronavirus replication by a combination of interferon- $\alpha 2 b$ and ribavirin. Sci. Rep. 2013, 3, 1686. [CrossRef] [PubMed]

177. Hart, B.; Dyall, J.; Postnikova, E.; Zhou, H.; Kindrachuk, J.; Johnson, R.F.; Jr, G.G.O.; Frieman, M.B.; Holbrook, M.R.; Jahrling, P.B.; et al. Interferon- $\beta$ and mycophenolic acid are potent inhibitors of Middle East respiratory syndrome coronavirus in cell-based assays. J. Gen. Virol. 2014, 95, 571-577. [CrossRef] [PubMed]

178. Chan, J.F.-W.; Yao, Y.; Yeung, M.L.; Deng, W.; Bao, L.; Jia, L.; Li, F.; Xiao, C.; Gao, H.; Yu, P.; et al. Treatment With Lopinavir/Ritonavir or Interferon- $\beta 1 \mathrm{~b}$ Improves Outcome of MERS-CoV Infection in a Nonhuman Primate Model of Common Marmoset. J. Infect. Dis. 2015, 212, 1904-1913. [CrossRef] 
179. Pan, Q.; de Ruiter, P.E.; Metselaar, H.J.; Kwekkeboom, J.; de Jonge, J.; Tilanus, H.W.; Janssen, H.L.; van der Laan, L.J. Mycophenolic acid augments interferon-stimulated gene expression and inhibits hepatitis C Virus infection in vitro and in vivo. Hepatol. 2011, 55, 1673-1683. [CrossRef] [PubMed]

180. Cheng, K.-W.; Cheng, S.-C.; Chen, W.-Y.; Lin, M.-H.; Chuang, S.-J.; Cheng, I.-H.; Sun, C.-Y.; Chou, C.-Y. Thiopurine analogs and mycophenolic acid synergistically inhibit the papain-like protease of Middle East respiratory syndrome coronavirus. Antivir. Res. 2015, 115, 9-16. [CrossRef] [PubMed]

181. Xu, X.; Han, M.; Li, T.; Sun, W.; Wang, D.; Fu, B.; Zhou, Y.; Zheng, X.; Yang, Y.; Li, X.; et al. Effective treatment of severe COVID-19 patients with tocilizumab. Proc. Natl. Acad. Sci. USA 2020, 117, 10970-10975. [CrossRef]

182. Ferro, F.; Elefante, E.; Baldini, C.; Bartoloni, E.; Puxeddu, I.; Talarico, R.; Mosca, M.; Bombardieri, S. COVID-19: The new challenge for rheumatologists. Clin. Exp. Rheumatol. 2020, 38, 175-180. [PubMed]

183. Bizzarri, M.; Laganà, A.S.; Aragona, D.; Unfer, V. Inositol and pulmonary function. Could myo-inositol treatment downregulate inflammation and cytokine release syndrome in SARS-CoV-2? Eur. Rev. Med. Pharmacol. Sci. 2020, 24, 3426-3432. [CrossRef]

184. Prokunina-Olsson, L.; Alphonse, N.; Dickenson, R.; Durbin, J.E.; Glenn, J.S.; Hartmann, R.; Kotenko, S.V.; Lazear, H.M.; O’Brien, T.R.; Odendall, C.; et al. COVID-19 and emerging viral infections: The case for interferon lambda. J. Exp. Med. 2020, 217, e20200653. [CrossRef]

185. Fu, Y.; Cheng, Y.; Wu, Y. Understanding SARS-CoV-2-Mediated Inflammatory Responses: From Mechanisms to Potential Therapeutic Tools. Virol. Sin. 2020, 35, 266-271. [CrossRef] [PubMed]

186. Sarzi-Puttini, P.; Giorgi, V.; Sirotti, S.; Marotto, D.; Ardizzone, S.; Rizzardini, G.; Antinori, S.; Galli, M. COVID-19, cytokines and immunosuppression: What can we learn from severe acute respiratory syndrome? Clin. Exp. Rheumatol. 2020, 38, 337-342.

187. Le, R.Q.; Li, L.; Yuan, W.; Shord, S.S.; Nie, L.; Habtemariam, B.A.; Przepiorka, D.; Farrell, A.T.; Pazdur, R. FDA Approval Summary: Tocilizumab for Treatment of Chimeric Antigen Receptor T Cell-Induced Severe or Life-Threatening Cytokine Release Syndrome. Oncologist 2018, 23, 943-947. [CrossRef] [PubMed]

188. Oldfield, V.; Dhillon, S.; Plosker, G.L. Tocilizumab: A review of its use in the management of rheumatoid arthritis. Drugs 2009, 69, 609-632. [CrossRef]

189. FDA. Actemra ${ }^{\circledR}($ tocilizumab) Injection, for Intravenous or Subcutaneous Use: Highlights of Prescribing Information. Available online: https:/ / www.accessdata.fda.gov/drugsatfda_docs/label/2013/125276s092lbl.pdf (accessed on 22 May 2021).

190. Heink, S.; Yogev, N.; Garbers, C.; Herwerth, M.; Aly, L.; Gasperi, C.; Husterer, V.; Croxford, A.L.; Möller-Hackbarth, K.; Bartsch, H.S.; et al. Trans-presentation of IL-6 by dendritic cells is required for the priming of pathogenic TH17 cells. Nat. Immunol. 2017, 18, 74-85. [CrossRef] [PubMed]

191. Kang, S.; Tanaka, T.; Narazaki, M.; Kishimoto, T. Targeting Interleukin-6 Signaling in Clinic. Immunity 2019, 50, 1007-1023. [CrossRef]

192. Velazquez-Salinas, L.; Verdugo-Rodriguez, A.; Rodriguez, L.L.; Borca, M.V. The Role of Interleukin 6 during Viral Infections. Front. Microbiol. 2019, 10, 1057. [CrossRef]

193. Neumann, A.U.; Goekkaya, M.; Dorgham, K.; Traidl-Hoffmann, C.; Gorochov, G. Tocilizumab in COVID-19 therapy: Who benefits, and how? Lancet 2021, 398, 299-300. [CrossRef]

194. Bracaglia, C.; Caiello, I.; De Graaf, K.; D’Ario, G.; Guilhot, F.; Ferlin, W.; Melli, L.; Prencipe, G.; Davì, S.; Schulert, G.; et al. Interferon-gamma (IFNy) in macrophage activation syndrome (MAS) associated with systemic juvenile idiopathic arthritis (sJIA). High levels in patients and a role in a murine mas model. Pediatr. Rheumatol. 2014, 12, O3. [CrossRef]

195. Kumar, P.; Sharma, A.; Sait, S.F.; Kumar, M. Ovarian hyperstimulation syndrome. J. Hum. Reprod. Sci. 2011, 4, 70-75. [CrossRef] [PubMed]

196. Preuss, S.; Stadelmann, S.; Omam, F.D.; Scheiermann, J.; Winoto-Morbach, S.; Von Bismarck, P.; Knerlich-Lukoschus, F.F.; Lex, D.; Adam-Klages, S.; Wesch, D.; et al. Inositol-Trisphosphate Reduces Alveolar Apoptosis and Pulmonary Edema in Neonatal Lung Injury. Am. J. Respir. Cell Mol. Biol. 2012, 47, 158-169. [CrossRef] [PubMed]

197. Spengler, D.; Winoto-Morbach, S.; Kupsch, S.; Vock, C.; Blöchle, K.; Frank, S.; Rintz, N.; Diekötter, M.; Janga, H.; Weckmann, M.; et al. Novel therapeutic roles for surfactant-inositols and -phosphatidylglycerols in a neonatal piglet ARDS model: A translational study. Am. J. Physiol. Lung Cell. Mol. Physiol. 2018, 314, L32-L53. [CrossRef] [PubMed]

198. Turan, G.A.; Eskicioğlu, F.; Sivrikoz, O.N.; Cengiz, H.; Adakan, S.; Gur, E.B.; Tatar, S.; Sahin, N.; Yilmaz, O. Myo-inositol is a promising treatment for the prevention of ovarian hyperstimulation syndrome (OHSS): An animal study. Arch. Gynecol. Obstet. 2015, 292, 1163-1171. [CrossRef] [PubMed]

199. Unver, N.; Delgado, O.; Zeleke, K.; Cumpian, A.; Tang, X.; Caetano, M.S.; Wang, H.; Katayama, H.; Yu, H.; Szabo, E.; et al. Reduced IL-6 levels and tumor-associated phospho-STAT3 are associated with reduced tumor development in a mouse model of lung cancer chemoprevention with myo- inositol. Int. J. Cancer 2018, 142, 1405-1417. [CrossRef]

200. Fuso, A.; Iyer, A.; Van Scheppingen, J.; Maccarrone, M.; Scholl, T.; Hainfellner, J.A.; Feucht, M.; Jansen, F.E.; Spliet, W.G.; Krsek, P.; et al. Promoter-Specific Hypomethylation Correlates with IL-1 $\beta$ Overexpression in Tuberous Sclerosis Complex (TSC). J. Mol. Neurosci. 2016, 59, 464-470. [CrossRef]

201. Nicolia, V.; Cavallaro, R.A.; López-González, I.; Maccarrone, M.; Scarpa, S.; Ferrer, I.; Fuso, A. DNA Methylation Profiles of Selected Pro-Inflammatory Cytokines in Alzheimer Disease. J. Neuropathol. Exp. Neurol. 2017, 76, 27-31. [CrossRef] [PubMed]

202. Al-Tawfiq, J.A.; Momattin, H.; Dib, J.; Memish, Z.A. Ribavirin and interferon therapy in patients infected with the Middle East respiratory syndrome coronavirus: An observational study. Int. J. Infect. Dis. 2014, 20, 42-46. [CrossRef] 
203. Omrani, A.; Saad, M.M.; Baig, K.; Bahloul, A.; Abdul-Matin, M.; Alaidaroos, A.Y.; Almakhlafi, G.A.; Albarrak, M.M.; Memish, Z.A.; Albarrak, A.M. Ribavirin and interferon alfa-2a for severe Middle East respiratory syndrome coronavirus infection: A retrospective cohort study. Lancet Infect. Dis. 2014, 14, 1090-1095. [CrossRef]

204. Galani, I.E.; Triantafyllia, V.; Eleminiadou, E.-E.; Koltsida, O.; Stavropoulos, A.; Manioudaki, M.; Thanos, D.; Doyle, S.E.; Kotenko, S.V.; Thanopoulou, K.; et al. Interferon- $\lambda$ Mediates Non-redundant Front-Line Antiviral Protection against Influenza Virus Infection without Compromising Host Fitness. Immunity 2017, 46, 875-890.e876. [CrossRef]

205. Davidson, S.; McCabe, T.M.; Crotta, S.; Gad, H.H.; Hessel, E.M.; Beinke, S.; Hartmann, R.; Wack, A. IFN $\lambda$ is a potent anti-influenza therapeutic without the inflammatory side effects of IFN $\alpha$ treatment. EMBO Mol. Med. 2016, 8, 1099-1112. [CrossRef]

206. Klinkhammer, J.; Schnepf, D.; Ye, L.; Schwaderlapp, M.; Gad, H.H.; Hartmann, R.; Garcin, D.; Mahlakõiv, T.; Staeheli, P. IFN- $\lambda$ prevents influenza virus spread from the upper airways to the lungs and limits virus transmission. eLife 2018, 7, e33354. [CrossRef] [PubMed]

207. Broggi, A.; Granucci, F.; Zanoni, I. Type III interferons: Balancing tissue tolerance and resistance to pathogen invasion. J. Exp. Med. 2019, 217, e20190295. [CrossRef] [PubMed]

208. Koltsida, O.; Hausding, M.; Stavropoulos, A.; Koch, S.; Tzelepis, G.; Übel, C.; Kotenko, S.V.; Sideras, P.; Lehr, H.A.; Tepe, M.; et al. IL-28A (IFN- $\lambda 2$ ) modulates lung DC function to promote Th1 immune skewing and suppress allergic airway disease. EMBO Mol. Med. 2011, 3, 348-361. [CrossRef]

209. Ye, L.; Schnepf, D.; Becker, J.; Ebert, K.; Tanriver, Y.; Bernasconi, V.; Gad, H.H.; Hartmann, R.; Lycke, N.; Staeheli, P. Interferon- $\lambda$ enhances adaptive mucosal immunity by boosting release of thymic stromal lymphopoietin. Nat. Immunol. 2019, 20 , 593-601. [CrossRef]

210. Espinosa, V.; Dutta, O.; McElrath, C.; Du, P.; Chang, Y.-J.; Cicciarelli, B.; Pitler, A.; Whitehead, I.; Obar, J.J.; Durbin, J.E.; et al. Type III interferon is a critical regulator of innate antifungal immunity. Sci. Immunol. 2017, 2. [CrossRef]

211. Goel, R.R.; Wang, X.; O’Neil, L.J.; Nakabo, S.; Hasneen, K.; Gupta, S.; Wigerblad, G.; Blanco, L.P.; Kopp, J.B.; Morasso, M.I.; et al. Interferon lambda promotes immune dysregulation and tissue inflammation in TLR7-induced lupus. Proc. Natl. Acad. Sci. USA 2020, 117, 5409-5419. [CrossRef]

212. Blazek, K.; Eames, H.L.; Weiss, M.; Byrne, A.; Perocheau, D.; Pease, J.; Doyle, S.; McCann, F.; Williams, R.O.; Udalova, I.A. IFN- $\lambda$ resolves inflammation via suppression of neutrophil infiltration and IL-1 $\beta$ production. J. Exp. Med. 2015, 212, 845-853. [CrossRef]

213. Rich, H.; McCourt, C.C.; Zheng, W.Q.; McHugh, K.J.; Robinson, K.M.; Wang, J.; Alcorn, J.F. Interferon Lambda Inhibits Bacterial Uptake during Influenza Superinfection. Infect. Immun. 2019, 87, e00114-19. [CrossRef]

214. Broggi, A.; Tan, Y.; Granucci, F.; Zanoni, I. IFN- $\lambda$ suppresses intestinal inflammation by non-translational regulation of neutrophil function. Nat. Immunol. 2017, 18, 1084-1093. [CrossRef]

215. Fabbi, M.; Carbotti, G.; Ferrini, S. Dual Roles of IL-27 in Cancer Biology and Immunotherapy. Mediat. Inflamm. 2017, 2017, 3958069. [CrossRef] [PubMed]

216. Fragoulis, G.E.; McInnes, I.B.; Siebert, S. JAK-inhibitors. New players in the field of immune-mediated diseases, beyond rheumatoid arthritis. Rheumatology 2019, 58, i43-i54. [CrossRef] [PubMed]

217. Virtanen, A.T.; Haikarainen, T.; Raivola, J.; Silvennoinen, O. Selective JAKinibs: Prospects in Inflammatory and Autoimmune Diseases. BioDrugs 2019, 33, 15-32. [CrossRef] [PubMed]

218. Richardson, P.; Griffin, I.; Tucker, C.; Smith, D.; Oechsle, O.; Phelan, A.; Rawling, M.; Savory, E.; Stebbing, J. Baricitinib as potential treatment for 2019-nCoV acute respiratory disease. Lancet 2020, 395, e30-e31. [CrossRef]

219. Tufan, A.; GÜLER, A.A.; Matucci-Cerinic, M. COVID-19, immune system response, hyperinflammation and repurposing antirheumatic drugs. Turk. J. Med Sci. 2020, 50, 620-632. [CrossRef]

220. Conti, P.; Gallenga, C.E.; Tete, G.; Caraffa, A.; Ronconi, G.; YouneS, A.; Toniato, E.; Ross, R.; Kritas, S.K. How to reduce the likelihood of coronavirus-19 (CoV-19 or SARS-CoV-2) infection and lung inflammation mediated by IL-1. J. Biol. Regul. Homeost. Agents 2020, 34, 11-16.

221. FDA. Kineret巴(anakinra) for Injection, for Subcutaneous Use: Highlights of Prescribing Information. Available online: https: //www.accessdata.fda.gov/drugsatfda_docs/label/2013/103950s51501bl.pdf (accessed on 19 May 2021).

222. Opal, S.M.; Fisher, C.J.; Dhainaut, J.-F.A.; Vincent, J.-L.; Brase, R.; Lowry, S.F.; Sadoff, J.C.; Slotman, G.J.; Levy, H.P.; Balk, R.A.; et al. Confirmatory interleukin-1 receptor antagonist trial in severe sepsis: A phase III, randomized, double-blind, placebo-controlled, multicenter trial. The Interleukin-1 Receptor Antagonist Sepsis Investigator Group. Crit. Care Med. 1997, 25, 1115-1124. [CrossRef] [PubMed]

223. Shakoory, B.; Carcillo, J.A.; Chatham, W.W.; Amdur, R.L.; Zhao, H.; Dinarello, C.A.; Cron, R.Q.; Opal, S.M. Interleukin-1 Receptor Blockade Is Associated with Reduced Mortality in Sepsis Patients with Features of Macrophage Activation Syndrome. Reanalysis of a Prior Phase III Trial. Crit. Care Med. 2016, 44, 275-281. [CrossRef] [PubMed]

224. Deftereos, S.G.; Siasos, G.; Giannopoulos, G.; Vrachatis, D.A.; Angelidis, C.; Giotaki, S.G.; Gargalianos, P.; Giamarellou, H.; Gogos, C.; Daikos, G.; et al. The Greek study in the effects of colchicine in COVID-19 complications prevention (GRECCO-19 study): Rationale and study design. Hell. J. Cardiol. 2020, 61, 42-45. [CrossRef]

225. Conti, P.; Ronconi, G.; Caraffa, A.; Gallenga, C.E.; Ross, R.; Frydas, I.; Kritas, S.K. Induction of pro-inflammatory cytokines (IL-1 and IL-6) and lung inflammation by Coronavirus-19 (CoV-19 or SARS-CoV-2): Anti-inflammatory strategies. J. Biol. Regul. Homeost. Agents 2020, 34. [CrossRef] 
226. Corporation, C. CytoSorb, the Wuhan Coronavirus, and Cytokine Storm. Available online: https:/ /www.prnewswire.com/newsreleases / cytosorb-the-wuhan-coronavirus-and-cytokine-storm-300994196.html (accessed on 22 May 2020).

227. Conner, E.M.; Grisham, M.B. Inflammation, free radicals, and antioxidants. Nutrition 1996, 12, 274-277. [CrossRef]

228. Sanguinetti, C.M. N-acetylcysteine in COPD: Why, how, and when? Multidiscip. Respir. Med. 2015, 11, 8. [CrossRef] [PubMed]

229. Monick, M.M.; Aksamit, T.R.; Geist, L.J.; Hunninghake, G.W. Dexamethasone inhibits IL-1 and TNF activity in human lung fibroblasts without affecting IL-1 or TNF receptors. Am. J. Physiol. Cell. Mol. Physiol. 1994, 267, L33-L38. [CrossRef] [PubMed]

230. Sinha, S.; Rosin, N.L.; Arora, R.; Labit, E.; Jaffer, A.; Cao, L.; Farias, R.; Nguyen, A.P.; McDonald, B.; Gillrie, M.; et al. An Immune Cell Atlas Reveals Dynamic COVID-19 Specific Neutrophil Programming Amendable to Dexamethasone Therapy. bioRxiv 2021. [CrossRef] 